\title{
Rapid evolution of silver nanoparticle resistance in Escherichia coli
}

\section{Joseph L. Graves Jr. ${ }^{1 *}{ }^{\dagger}$, Mehrdad Tajkarimi ${ }^{2}$, Quincy Cunningham ${ }^{3}$, Adero Campbell ${ }^{4}$, Herve Nonga ${ }^{5}$, Scott H. Harrison ${ }^{3 \dagger}$ and Jeffrey E. Barrick ${ }^{6+}$}

' Department of Nanoengineering, Joint School for Nanoscience and Nanoengineering, North Carolina Agricultural and Technical State University/University of North Carolina, Greensboro, NC, USA

2 Department of Nanoscience, Joint School for Nanoscience and Nanoengineering, North Carolina Agricultural and Technical State University/University of North Carolina, Greensboro, NC, USA

${ }^{3}$ Department of Biology, North Carolina Agricultural and Technical State University, Greensboro, NC, USA

${ }^{4}$ Department of Biology, Bennett College, Greensboro, NC, USA

${ }^{5}$ Student Research Opportunity Program, Michigan State University, East Lansing, MI, USA

${ }^{6}$ Department of Molecular Biosciences, The University of Texas at Austin, Austin, TX, USA

\section{Edited by:}

Olivier Antoine Tenaillon, Institut National de la Santé et de la Recherche Médicale, France

\section{Reviewed by:}

René Massimiliano Marsano,

University of Bari, Italy

Joë Gaffé, Univerty of Grenoble,

France

\section{*Correspondence:}

Joseph L. Graves Jr., Department of Nanoengineering, Joint School for Nanoscience and Nanoengineering, North Carolina Agricultural and Technical State University/University of North Carolina, 2907 E. Lee St.,

Greensboro, NC 27401, USA

e-mail: gravesj|@ncat.edu

${ }_{\text {BEACON Center for the Study of }}$ Evolution in Action.
The recent exponential increase in the use of engineered nanoparticles (eNPs) means both greater intentional and unintentional exposure of eNPs to microbes. Intentional use includes the use of eNPs as biocides. Unintentional exposure results from the fact that eNPs are included in a variety of commercial products (paints, sunscreens, cosmetics). Many of these eNPs are composed of heavy metals or metal oxides such as silver, gold, zinc, titanium dioxide, and zinc oxide. It is thought that since metallic/metallic oxide NPs impact so many aspects of bacterial physiology that it will difficult for bacteria to evolve resistance to them. This study utilized laboratory experimental evolution to evolve silver nanoparticle (AgNP) resistance in the bacterium Escherichia coli (K-12 MG1655), a bacterium that does not harbor any known silver resistance elements. After 225 generations of exposure to the AgNP environment, the treatment populations demonstrated greater fitness vs. control strains as measured by optical density (OD) and colony forming units (CFU) in the presence of varying concentrations of $10 \mathrm{~nm}$ citrate-coated silver nanoparticles (AgNP) or silver nitrate $\left(\mathrm{AgNO}_{3}\right)$. Genomic analysis shows that changes associated with AgNP resistance were already accumulating within the treatment populations by generation 100, and by generation 200 three mutations had swept to high frequency in the AgNP resistance stocks. This study indicates that despite previous claims to the contrary bacteria can easily evolve resistance to AgNPs, and this occurs by relatively simple genomic changes. These results indicate that care should be taken with regards to the use of eNPs as biocides as well as with regards to unintentional exposure of microbial communities to eNPs in waste products.

Keywords: eNPs, AgNPs, E. coli, Genomics, adaptation

\section{INTRODUCTION}

Experimental evolution is routinely used to study the causes and consequences of natural selection. Specifically experimental evolution can predict how phenotypes and their underlying genomic architecture change in response to new environments. This approach may be particular fertile for bacterial evolution. While these organisms have persisted and diversified for billions of years, they often must respond to novel environments. For example, the exponential increase in products utilizing nanomaterials (NMs) will mean increased exposure to NMs for a variety of microbes. Increasing amounts of metallic/metallic oxide nanoparticles are being used in consumer products. Nano-titanium oxide (nano$\mathrm{TiO}_{2}$ ) is produced on a large scale for applications in paints, cosmetics, sunscreens, photo-catalysts and solar cells, as well as water purification devices. The predicted concentration of nanoTiO 2 in European waters for 2009 was $20 \mathrm{ng} / \mathrm{L}$ (Gottschalk et al., 2009). Similarly values for nano-silver were calculated at $6.6 \mu \mathrm{g} / \mathrm{kg} /$ year, $526 \mu \mathrm{g} / \mathrm{kg} /$ year, $0.088 \mu \mathrm{g} / \mathrm{L} /$ year, $16.40 \mu \mathrm{g} / \mathrm{L} /$ year, $1.29 \mathrm{mg} / \mathrm{kg} /$ year, and $153 \mu \mathrm{g} / \mathrm{kg} /$ year for American soil, sludge, surface water, Sewage Treatment Plant (STP) effluent, STP sludge, and sediment respectively.

In addition, metallic and metallic oxide nanoparticles are being hailed by some as a powerful new weapon against multidrug resistant bacteria (Rai et al., 2012). This is motivated by recognizing that noble metals such as silver have a long history as antimicrobial agents with use dating back at least to $1000 \mathrm{BCE}$. In modern times, nano silver, copper, and silica have been successfully used in a variety of settings as both antimicrobial and anti-insecticidal compounds. Nanosilver is now being widely used in food packaging materials and also being proposed for use in surgical gowns and surgical gauze (Li et al., 2006; Siqueira et al., 2014). Silver nanoparticles (AgNPs) have been shown to 
be protective agents against numerous species of bacteria, including Escherichia coli, Enterococcus faecalis, Staphylococcus aureus, and several others. Other metallic and metallic oxide nanoparticles have also been employed against bacteria including titanium oxide $\left(\mathrm{TiO}_{2}\right)$, magnesium oxide $(\mathrm{MgO})$, copper $(\mathrm{Cu})$, copper oxide $(\mathrm{CuO})$, zinc oxide $(\mathrm{ZnO})$, cadmium selenium $(\mathrm{CdSe})$ and cadmium telluride (CdTe), (Duncan, 2011).

The effectiveness of NPs against both bacteria and viruses are due to their high surface-to-volume ratio and their unique chemical and physical properties. Numerous studies have now shown that the toxicity of NPs against bacteria appears dependent on particle composition, shape, size, and concentration (for AgNPs, concentrations of $>75 \mu \mathrm{g} / \mathrm{ml}$ usually completely inhibits growth; Rai et al., 2012; Tajkarimi et al., 2014). While the exact mechanisms of silver nanoparticle toxicity to bacteria are not fully known, there is a growing consensus concerning the candidate actions. First, the action of silver nanoparticles occurs both by the release of silver ion $\left(\mathrm{Ag}^{+}\right)$as well as from potential disruption or damage to the cell wall and membrane caused by the particles themselves (Rai et al., 2009, 2012; Mijnendonckx et al., 2013). Silver interacts with the thiol groups in respiratory enzymes and other proteins of bacterial cells causing them to become inactivated (Liau et al., 1997; Feng et al., 2000). It also binds to the cell wall and cell membrane inhibiting the respiration process (Klasen, 2000; Rai et al., 2009). Silver is known to act on $E$. coli by inhibiting the uptake of phosphorous and causing the release of phosphate, mannitol, succinate, proline, and glutamine from the cells (Yamanaka et al., 2005; Rai et al., 2012). The penetration of silver ions inside the cell is thought to impact the ability of DNA to replicate by causing it to condense. Thus once inside, $\mathrm{Ag}^{+}$ions may be lethal as they disrupt metabolism, cell signaling, DNA replication, transcription, translation, and cell division, either directly or through the generation of reactive oxygen species (ROS) (Rai et al., 2012; Mijnendonckx et al., 2013). It is the fact that metallic/metallic oxides impact so many aspects of bacterial physiology and reproduction that has led some researchers to suggest that it will be difficult for bacteria to evolve resistance to them (e.g., see discussion in Rai et al., 2012). However, despite this claim, silver-resistant bacteria have been repeatedly found in burn wards, clinical and natural environments, and on human teeth (Mijnendonckx et al., 2013). Given the projections concerning deployment of metallic, particularly silver nanoparticles for bacterial control it is important to evaluate the evolvability of resistance to them (Gupta and Silver, 1998; Graves, 2014). This experiment utilizes a relatively naïve laboratory bacterium, E. coli K-12 MG1655, to determine both how quickly resistance to AgNPs can evolve and also to evaluate the nature of the genomic changes responsible for such resistance.

\section{MATERIALS AND METHODS BACTERIA}

E. coli K-12 MG1655 (ATCC \#47076) was chosen for this study due to the paucity of known silver or antibiotic resistant loci in this bacterium. There are no plasmids in this strain, and the circular chromosome is composed of 4,641,652 nucleotides (GenBank: NC_000913.3; Riley et al., 2006). Table 1 lists major antimicrobial resistance genes found in various microorganisms, and their presence or absence in MG1655.
Table 1 | Major antimicrobial resistance genes in Escherichia coli.

\begin{tabular}{|c|c|c|c|}
\hline $\begin{array}{l}\text { Antimicrobial } \\
\text { agent }\end{array}$ & Genes & MG1655 & References \\
\hline Streptomycin & aadA1 & No & Momtaz et al., 2012 \\
\hline Gentamicin & $\operatorname{aac}(3)-I / V$ & No & \\
\hline Sulfonamide & sul1, bla SHV, bla, CMY & No & \\
\hline \multirow[t]{2}{*}{ Beta lactams } & $k p c, c m y-2$, shv, tem & No & Xia et al., 2011 \\
\hline & ctx-m, lap-1, bla-tem & No & \\
\hline Ampicillin & $\operatorname{ere}(A)$ & No & \\
\hline Erythromycin & cat $A 1$ & No & Momtaz et al., 2012 \\
\hline Chloramphenicol & $c m 1 A$ & No & \\
\hline Tetracycline & $\operatorname{tet}(A), \operatorname{tet}(B)$ & No & \\
\hline Trimethoprim & $d f r A 1$ & No & \\
\hline Quinolones & qnr $A$ & No & \\
\hline Sulfonamide & sul1, sul2 & No & Tadesse et al., 2012 \\
\hline Silver & silE, sil-CFBA & No & $\begin{array}{l}\text { Gupta et al., 2001; } \\
\text { Silver, } 2003\end{array}$ \\
\hline Silver & $\begin{array}{l}\text { cusS, ompA, ompB, } \\
\text { ompF, ybdE }\end{array}$ & Yes & $\begin{array}{l}\text { Li et al., 1997; Franke } \\
\text { et al., 2001; } \\
\text { Gudipathy and } \\
\text { McEvoy, } 2014\end{array}$ \\
\hline
\end{tabular}

\section{EVOLUTION EXPERIMENT}

We cultured E. coli K-12 MG1655 using Davis Minimal Broth (DMB, Difco ${ }^{\mathrm{TM}}$ Sparks, MD ) with Dextrose $10 \%$ (Dextrose, Fisher Scientific, Fair Lawn, NJ) as a sole carbon source, enriched with thiamine hydrochloride $0.1 \%$ in $10 \mathrm{ml}$ of total culture volume maintained in $50 \mathrm{ml}$ Erlenmeyer flasks. The flasks were placed in a shaking incubator with temperature maintained at $37^{\circ} \mathrm{C}$ for $24 \mathrm{~h}$. The stock culture was propagated by daily transfers of $0.1 \mathrm{ml}$ of each culture into $9.9 \mathrm{ml}$ of DMB for 11 days of regrowth before selection for AgNP resistance began. The controls were founded by taking five different $0.1 \mathrm{ml}$ samples and adding them to $9.9 \mathrm{ml}$ of DMB broth. These cultures were allowed to grow for $24 \mathrm{~h}$, typically representing 6.5 generations of population growth from $\sim 10^{6}$ cells per $\mathrm{ml}$ at hour $0-10^{8}$ cells per $\mathrm{ml}$ at $24 \mathrm{~h}$. On the following day the treatment groups were founded by taking $0.1 \mathrm{~mL}$ samples from each of the controls and adding them to $9.9 \mathrm{ml}$ of standard DMB medium with the addition of $50 \mu \mathrm{g} / \mathrm{L}$ or $50,000 \mathrm{ng} / \mathrm{L}$ concentration of $10 \mathrm{~nm}$ citrate-coated spherical AgNPs. The nanoparticles were obtained from Nanocomposix, San Diego, CA. The AgNPs were citrate-coated due to the need to prevent agglomeration of the particles. Citrate was chosen for this experiment due to the inability of citrate to be metabolized by E. coli (Scheutz and Strockbine, 2005).

Our laboratory has studied the impact of two commonly used silver nanoparticle coating types (citrate and polyvinylpyrolidone, PVP) on bacteria (Tajkarimi et al., 2014). Generally, we have found that citrate-coated AgNPs were more effective against E. coli K-12 MG1655 than PVP-coated AgNPs. The impact of citrate coating is most likely due to the charge of citrate impacting the rate of release of $\mathrm{Ag}^{+}$ion, as opposed to the compound itself (El Badawy et al., 2011; Xiu et al., 2012). Control populations were designed $\left(\mathrm{C}_{1}-\mathrm{C}_{5}\right)$ and those cultured in AgNPs were designed as $\left(\mathrm{T}_{1}-\mathrm{T}_{5}\right)$. Each five generations, after transfer to found the next generation, the remainder of each replicate was frozen at $-80^{\circ} \mathrm{C}$ 
for future analysis. The generation counts used in this study are based upon the number of cell doublings of $E$. coli required to grow to saturation each day after dilution in the standard DMB broth (controls grew $\sim 6.5$ generations/per day.) We know that the treatment populations were at least 6 generations behind the controls, since they were founded $24 \mathrm{~h}$ later. In addition, it is unclear whether the bacteria exposed to AgNPs were able to maintain the same number of cell doublings as the controls due to the presence of AgNPs in their environment. This was most likely the case early in the selection experiment, but later measurements of the treatment populations in the presence of AgNPs suggest that they achieved full growth each day after they acquired adaptations allowing them to persist in the AgNP environment.

It was determined that $50 \mu \mathrm{g} / \mathrm{L}(50,000 \mathrm{ng} / \mathrm{L})$ of $\mathrm{AgNPs}$ allowed some bacterial growth as indicated by observable turbidity after $24 \mathrm{~h}$ of exposure. This concentration was chosen as the starting point for the resistance studies. After 50 generations of culture, the culture concentration of the treatment populations was increased to $100 \mu \mathrm{g} / \mathrm{L}(100,000 \mathrm{ng} / \mathrm{L})$. This level was maintained for another 90 generations. After this the selection concentration was increased to $125 \mu \mathrm{g} / \mathrm{L}(125,000 \mathrm{ng} / \mathrm{L})$. This concentration was continued for another 125 generations. After 45 generations of exposure at this concentration it was observed that several of treatment replicates were losing viability. To rescue these populations, all replicates were combined. Five new replicates were created by sampling from the mixed pool. These were propagated without selection for AgNP resistance for an additional 40 generations before the new replicates were again exposed to another 80 generations of $125 \mu \mathrm{g} / \mathrm{L}(125,000 \mathrm{ng} / \mathrm{L})$ AgNPs.

After 45 generations of growth in $125 \mu \mathrm{g} / \mathrm{L}(125,000 \mathrm{ng} / \mathrm{L})$ AgNPs, these replicates were combined to form a "cocktail" to assay their silver resistance relative to a similarly combined cocktail of control populations. The cocktail protocol was used due to a shortage of labor and materials. Figure 1 shows the schedule of exposure concentrations used in the selection protocol. After 140 generations of culture the exposure for the AgNP selected cultures had increased by $250 \%$.

\section{MEASURING BACTERIAL GROWTH}

Bacterial growth in $\mathrm{BHI}$ broth samples was assessed by measuring turbidity at $620 \mathrm{~nm}$ for hours $0,3,6,12$, and 24, using a 98-well plate Synergic Mx spectrophotometer (Biotek, VA USA) using clear polyester 98 -well plates.

\section{BACTERIAL ENUMERATION}

Bacterial populations were determined by spread plating on Davis Minimal Agar (DMA, Sigma Aldrich). In this procedure, samples were withdrawn from inoculated samples at 0 and $24 \mathrm{~h}$ and were

\section{Ancestral ATCC@ E.coli K12 MG1655}

\section{For 11 days: transferred $0.1 \mathrm{ml}$ in $9.9 \mathrm{ml}$ DMB broth}

\section{Day 12: $\mathrm{C}_{1}-\mathrm{C}_{5}$ replicates created}

\section{Day 13: $T_{1}-T_{5}$ replicates sampled from $C_{1}-C_{5}$ replicates}

Day 14: Begin common generation counting, T's on $50 \mu \mathrm{g} / \mathrm{L}$ AgNPs for 50 generations

\section{Day 17: T's on $100 \mu \mathrm{g} / \mathrm{L}$ for 90 generations}

\section{Day 30: T's on $125 \mu \mathrm{g} / \mathrm{L}$ for 45 generations}

\section{Day 37: T's and C's mixed, T's on $0 \mu \mathrm{g} / \mathrm{L}$ for 40 generations}

\section{Day 43: T's returned to $125 \mu \mathrm{g} / \mathrm{L}$ for 80 generations}

FIGURE 1 | Evolutionary history of control and treatment populations used in this study. 
serially diluted in $0.1 \%$ peptone water. Appropriate dilutions were plated $(200 \mu \mathrm{l})$ onto duplicate DMA plates and colonies were counted after incubation at $37^{\circ} \mathrm{C}$ overnight.

\section{MINIMUM INHIBITORY CONCENTRATION (MIC)}

MIC (Minimum Inhibitory concentration) is often defined in different terms; however we used "lowest concentration of a particular substance needed to inhibit the growth of a certain population of bacteria" (Kedziora et al., 2013). In this study we used MIC to mean the concentration that inhibited any visible growth of the organism over $24 \mathrm{~h}$. MICs were determined via serial dilution.

\section{GENOMIC ANALYSIS}

Whole genome resequencing was utilized to identify genomic variants associated with the greater $\mathrm{AgNP}$ and $\mathrm{AgNO}_{3}$ resistance of the treatment populations compared to the controls. DNA was extracted from each replicate population at generation 100 and generation 200 that had been stored in the $-80^{\circ} \mathrm{C}$ freezer $\left(\mathrm{C}_{1}-\right.$ $\mathrm{C}_{5} ; \mathrm{T}_{1}-\mathrm{T}_{5}$ ) as well as from the ancestral E. coli K-12 MG1655 stock obtained from ATCC (designated $\mathrm{C}_{0}$ ) for the genomic studies. The cells used for DNA extraction were cultured for $24 \mathrm{~h}$ in standard DM broth (without AgNPs). Cell density in these cultures was $\sim 10^{8}$ cells $/ \mathrm{ml}$. Extraction of DNA followed the protocol from Nucleic Acid Sample Preparation for Downstream Analysis: Principles \& Methods (GE Health Life Sciences, 2014). The DNA samples were sequenced via the Illumina MiSeq sequencing platform utilizing the Illumina Nextera XT kit for genomic library preparation.

Prior to sequence alignment and variant calling, the Illumina adapter sequences were removed from the MiSeq reads via Partek (http://www.partek.com/). Sequence alignment and variant calling from the generation 100 and 200 samples was achieved by use of the breseq 0.24 rc6 pipeline (Barrick et al., 2009; Deatherage and Barrick, 2014). The breseq program identifies mutations relative to a reference genome sequence. It is capable of identifying genomic variants including single nucleotide polymorphisms (SNPs), insertion-deletion polymorphisms (indels), and mutations caused by transposable insertion sequence (IS) elements.

\section{RESULTS}

\section{PHENOTYPES}

Population growth of the control $\left(\mathrm{C}_{1}-\mathrm{C}_{5}\right)$ and treatment $\left(\mathrm{T}_{1}-\right.$ $\mathrm{T}_{5}$ ) populations were measured at generation 162 and 250 in the presence of $10 \mathrm{~nm}$ citrate-coated AgNPs by cocktailing the control and treatment replicates. Figure 2 shows the optical density measurement of population growth for control (red circles) and treatment (blue squares) cocktails at generation 162 for $0 \mu \mathrm{g} / \mathrm{L}$ (solid line) and $250 \mu \mathrm{g} / \mathrm{L}(250,000 \mathrm{ng} / \mathrm{L}$, dashed line) citratecoated AgNPs. Controls showed slightly more rapid growth in the absence of AgNPs, and at $250 \mu \mathrm{g} / \mathrm{L}$ controls showed no growth. At $250 \mu \mathrm{g} / \mathrm{L}$ the treatment cocktail growth was delayed by $12 \mathrm{~h}$ before growth began. The treatments were able to show approximately a 100-fold increase through growth to saturation during the final $12 \mathrm{~h}$. Neither group showed any growth at higher concentrations $(500,1000 \mu \mathrm{g} / \mathrm{L} ; 500,000 \mathrm{ng} / \mathrm{L}, 1,000,000 \mathrm{ng} / \mathrm{L}$.

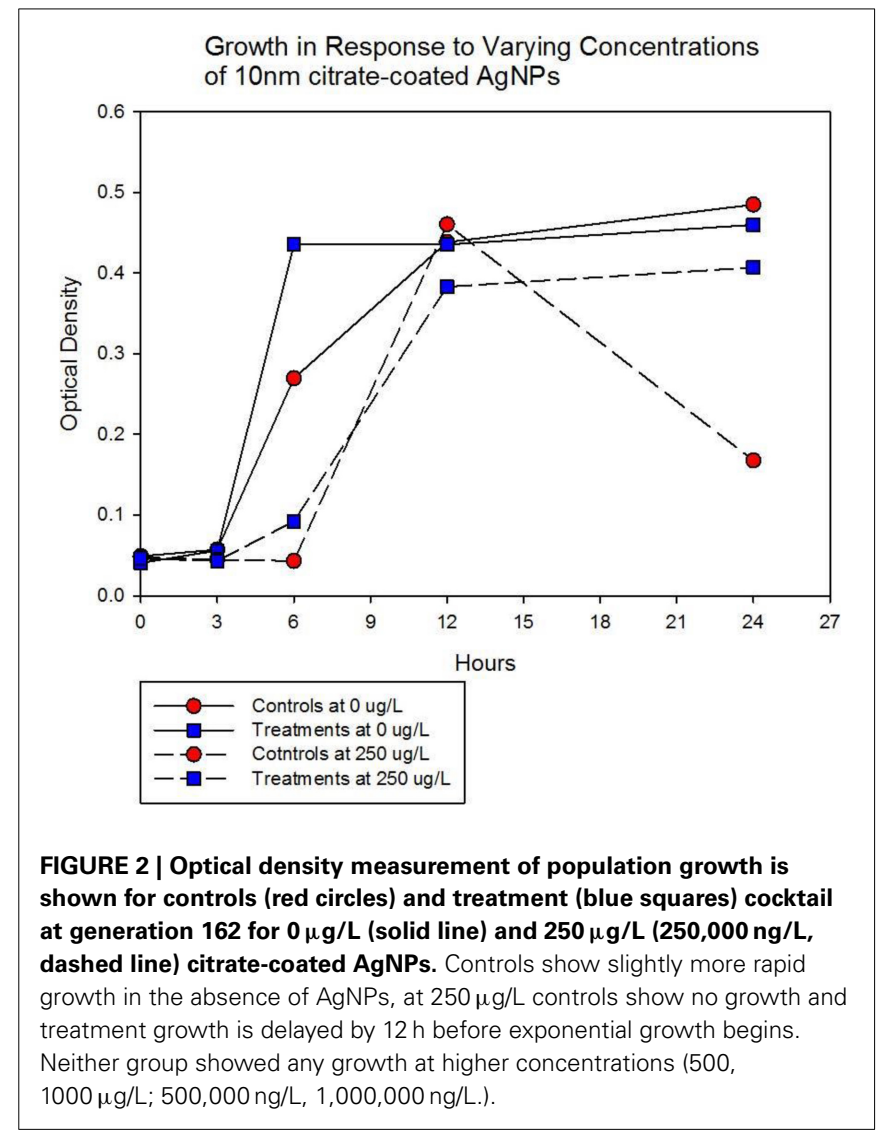

Figures 3A,B show optical density (OD) measured growth from generation 250 for a cocktail of control and treatment bacteria at the following concentrations of $\operatorname{AgNPs}(0,250,500$, and $750 \mu \mathrm{g} / \mathrm{L})$. In Figure 3A the optical density growth $(0.04-0.50)$ of the controls and treatment populations in $0 \mu \mathrm{g} / \mathrm{L} \mathrm{AgNPs}$ corresponded to a 100 -fold population increase. This was determined by counting colony-forming units (CFUs) for the cocktails without AgNPs over that same time period. At $250 \mu \mathrm{g} / \mathrm{L}$ both populations show a lag in growth (exponential phases starting at $\sim 6 \mathrm{~h}$ ) and at $24 \mathrm{~h}$ the treatment populations are showing superior growth relative to the control cocktail that shows a decrease in OD from hour 12 to 24 . Figure 3B demonstrates that there is no detectable growth of the control cocktail at both concentrations of 500 and $750 \mu \mathrm{g} / \mathrm{L}$ (750,000 ng/L) AgNPs. Conversely, growth is observed in the treatment cocktail, which at $500 \mu \mathrm{g} / \mathrm{L}$ shows an exponential phase after $6 \mathrm{~h}$, but is depressed in growth relative to the absence of AgNPs in the medium (Figure 3A). At $750 \mu \mathrm{g} / \mathrm{L}$ AgNPs the treatment cocktail shows an exponential phase after $12 \mathrm{~h}$ and at $24 \mathrm{~h}$ has reached a concentration similar to that observed in $250 \mu \mathrm{g} / \mathrm{L}$.

Figure 4A shows the growth of the control and treatment cocktails in response to $\mathrm{AgNO}_{3}$ (ionic silver). Both cocktail populations in $0 \mu \mathrm{g} / \mathrm{L} \mathrm{AgNO}_{3}$ exhibit a $2 \log _{10}$ population increase. At $250 \mu \mathrm{g} / \mathrm{L}$ the treatment cocktail does not show an growth phase until after $3 \mathrm{~h}$, but grows to almost a $2 \log _{10}$ increase. At this concentration control cocktail does not show an exponential phase until after $6 \mathrm{~h}$ and only shows a $1 \log _{10}$ increase. Figure $4 \mathrm{~B}$ 


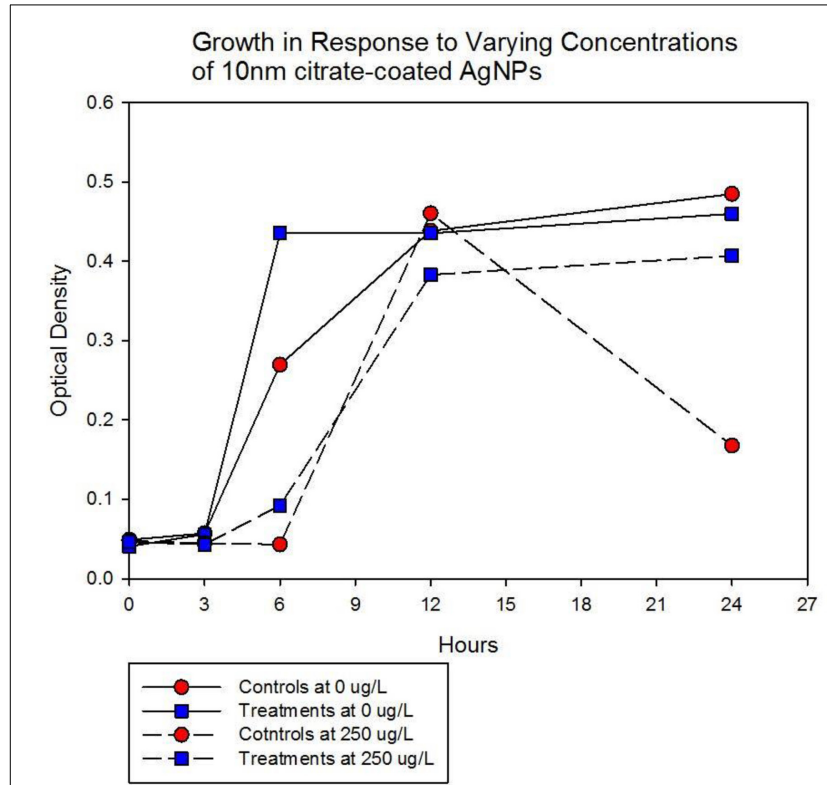

FIGURE 3A | Population growth over $24 \mathrm{~h}$ is shown for control (red circles) and treatment (blue squares) cocktails in response to varying concentrations of $10 \mathrm{~nm}$ citrate-coated NPs at generation 250. The growth of the controls and treatment populations in $0 \mu \mathrm{g} / \mathrm{L} \mathrm{AgNPs}$ corresponded to $2 \log _{10}$ population increase. At $250 \mu \mathrm{g} / \mathrm{L}$ both populations show a lag in growth (exponential phases starting at $\sim 6 \mathrm{~h}$ ) and at $24 \mathrm{~h}$ the treatment populations are showing superior growth relative to the control (that shows decrease from hour 12 to 24 .)

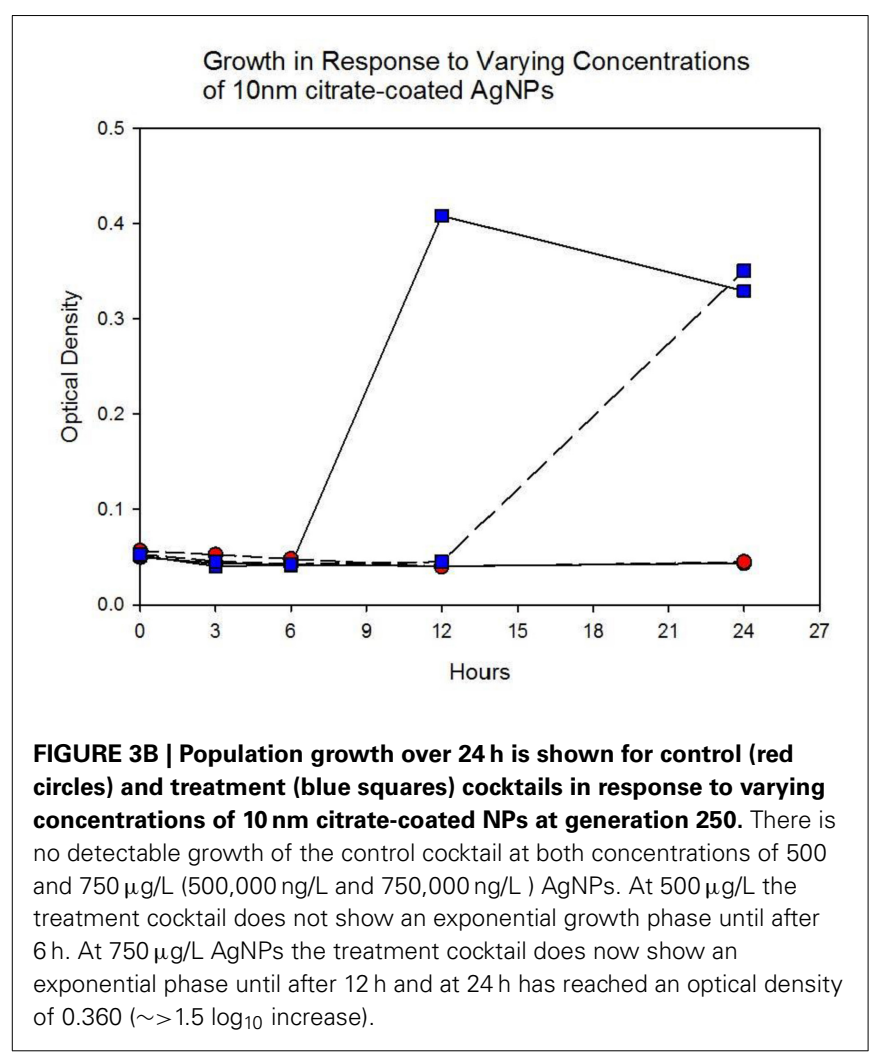

Growth in Response to Varying Concentrations of $\mathrm{AgNO} 3$

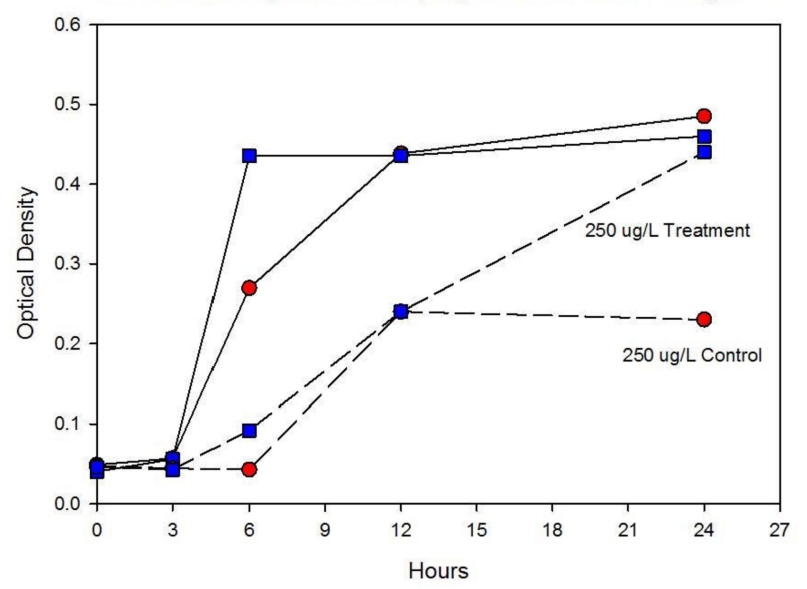

FIGURE 4A | Population growth over $24 \mathrm{~h}$ is shown for control and treatment cocktails in response to varying concentrations of $\mathrm{AgNO}_{3}$ at generation 250. The growth of the controls and treatment populations in $0 \mu \mathrm{g} / \mathrm{L} \mathrm{AgNO}_{3}$ corresponded to $2 \log _{10}$ population increase. At $250 \mu \mathrm{g} / \mathrm{L}$ the treatment cocktail does not show an exponential phase until after $3 \mathrm{~h}$, but grows to almost a $2 \log _{10}$ increase. At this concentration control cocktail does not show an exponential phase until after $6 \mathrm{~h}$ and only shows a $1 \log _{10}$ increase.

Growth in Response to Varying Concentrations of $\mathrm{AgNO} 3$

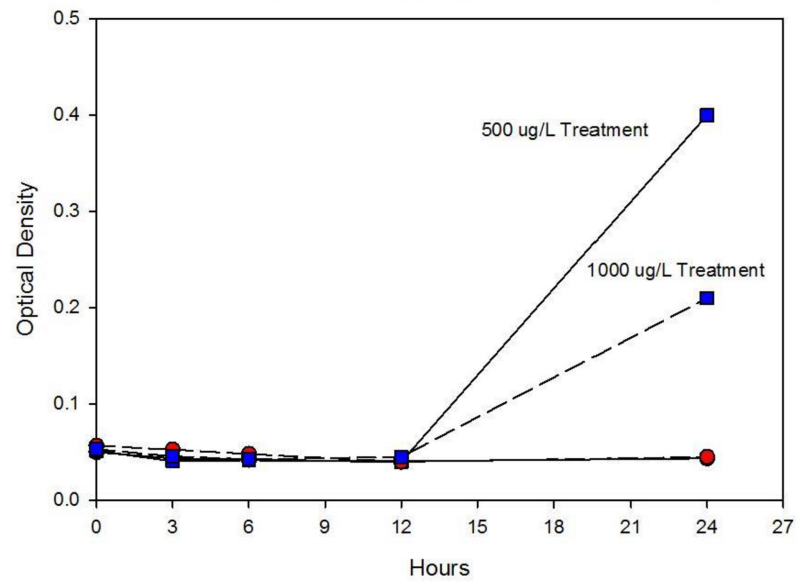

FIGURE 4B | Population growth over $24 \mathrm{~h}$ is shown for control and treatment cocktails in response to varying concentrations of $\mathrm{AgNO}_{3}$ at generation 250. There is no detectable growth of the control cocktail at both concentrations of 500 and $1000 \mu \mathrm{g} / \mathrm{L}$. At $500 \mu \mathrm{g} / \mathrm{L}$ the treatment cocktail does not show an exponential phase until after $12 \mathrm{~h}$, but is depressed in growth relative to the absence of $\mathrm{AgNO}_{3}$ in the medium (Figure 3A). At $1000 \mu \mathrm{g} / \mathrm{L}(1,000,000 \mathrm{ng} / \mathrm{L}) \mathrm{AgNO}_{3}$ the treatment cocktail does now show an exponential phase until after $12 \mathrm{~h}$ and at $24 \mathrm{~h}$ is about $1 \log _{10}$ increase.

shows population growth for control and treatment cocktails in response to 500 and $1000 \mu \mathrm{g} / \mathrm{L}$ of $\mathrm{AgNO}_{3}$. There is no detectable growth of the control cocktail at both concentrations of 500 and $1000 \mu \mathrm{g} / \mathrm{L}$. At $500 \mu \mathrm{g} / \mathrm{L}$ the treatment cocktail does not show an 
exponential phase until after $12 \mathrm{~h}$, but is depressed in growth relative to the absence of $\mathrm{AgNO}_{3}$ in the medium (Figure 4A). At $1000 \mu \mathrm{g} / \mathrm{L} \mathrm{AgNO}_{3}$ the treatment cocktail does not show growth until after $12 \mathrm{~h}$ and at $24 \mathrm{~h}$ shows about a 10 -fold increase in cell density.

Figure 5A shows population growth measured by colony forming units over $24 \mathrm{~h}$ for control and treatment cocktails in response to varying concentrations of $10 \mathrm{~nm}$ AgNPs at generation 250. Colony forming unit (CFU) measurement is considered a more accurate estimate of bacterial population size compared to optical density (OD). The Figure shows that the CFU and OD results agree. Both cocktails increased by $2.4 \log _{10}$ in the absence of AgNPs. There is no detectable difference in growth of the control and treatment cocktails at $100 \mu \mathrm{g} / \mathrm{L}$. However at 250, 500, and $1000 \mu \mathrm{g} / \mathrm{L}$ the treatment cocktail shows superior growth. At $500 \mu \mathrm{g} / \mathrm{L}$ the treatment cocktail is still growing while the control has shown $-1.9 \log _{10}$ decrease, at $1000 \mu \mathrm{g} / \mathrm{L}$ both have decreased with the treatment cocktail showing less reduction. Figure 5B shows population growth measured by colony forming units over $24 \mathrm{~h}$ for control and treatment cocktails in response to varying concentrations of $\mathrm{AgNO}_{3}$ at generation 250. Both cocktails increased by $2.4 \log _{10}$ in the absence of AgNPs. The data indicate that $\mathrm{AgNO}_{3}$ is more effective in reducing bacterial growth compared to the $10 \mathrm{~nm}$ AgNPs. This is illustrated by the fact that while the treatment shows positive growth exceeding the control cocktail by $\sim 2 \log _{10}$ units at

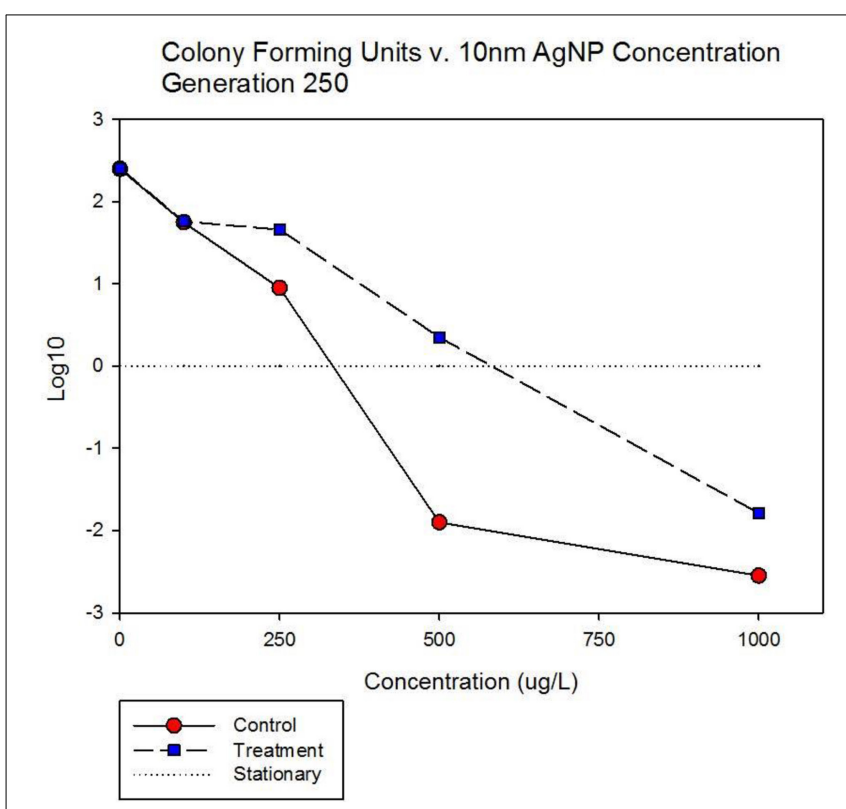

FIGURE 5A | Population growth measured by colony forming units over $\mathbf{2 4} \mathrm{h}$ is shown for control and treatment cocktails in response to varying concentrations of $\mathbf{1 0} \mathbf{~ n m ~ A g N P s ~ a t ~ g e n e r a t i o n ~ 2 5 0 . ~ B o t h ~}$ cocktails increased by $2.4 \log _{10}$ in the absence of AgNPs. There is no detectable difference in growth of the control and treatment cocktails at $100 \mu \mathrm{g} / \mathrm{L}$. However at 250,500, and $1000 \mu \mathrm{g} / \mathrm{L}$ the treatment cocktail shows superior growth. At $500 \mu \mathrm{g} / \mathrm{L}$ the treatment cocktail is still growing while the control has shown $-1.9 \log _{10}$ decrease, at $1000 \mu \mathrm{g} / \mathrm{L}$ both have decreased with the treatment cocktail showing less reduction.
$100 \mu \mathrm{g} /$; both cocktails show decrease at 250, 500, and $1000 \mu \mathrm{g} / \mathrm{L}$ with the treatment cocktail showing less reduction at all concentrations.

The data from both optical density (OD) and colony forming units (CFU) taken together indicate that by generation 250 of selection $(\sim 38.5$ days $)$ the treatment populations had evolved resistance to both citrate-coated $10 \mathrm{~nm}$ AgNPs and $\mathrm{AgNO}_{3}$ (ionic silver). Resistance to $10 \mathrm{~nm}$ PVP-coated AgNPs, $40 \mathrm{~nm}$ citrate and PVP-coated AgNPs was also illustrated by generation 250 (data not shown).

\section{GENOMICS}

Tables 2A,B show the genomic variants there were found in the E. coli K-12 MG1655 sample received from ATCC, relative to the published K-12 MG1655 genome via breseq. This pipeline uses three types of evidence to predict mutations, read alignments (RA), missing coverage (MC), and new junctions (JC) (Deatherage and Barrick, 2014). Any reads that indicate a difference between the sample and the reference genome that cannot be resolved to describe precise genetic changes are listed as "unassigned." The unassigned results are not reported in this paper. The variants can be called by either consensus or polymorphism mode. In the former, only variants that are consistent with being present in $100 \%$ of the reads in a sample are predicted, and in the latter, variants present at intermediate frequencies are reported. The data in Table 2 are reported in polymorphism mode. These indicate that there are a few differences between the ancestral sample of E. coli MG1655 and the reference genome that have

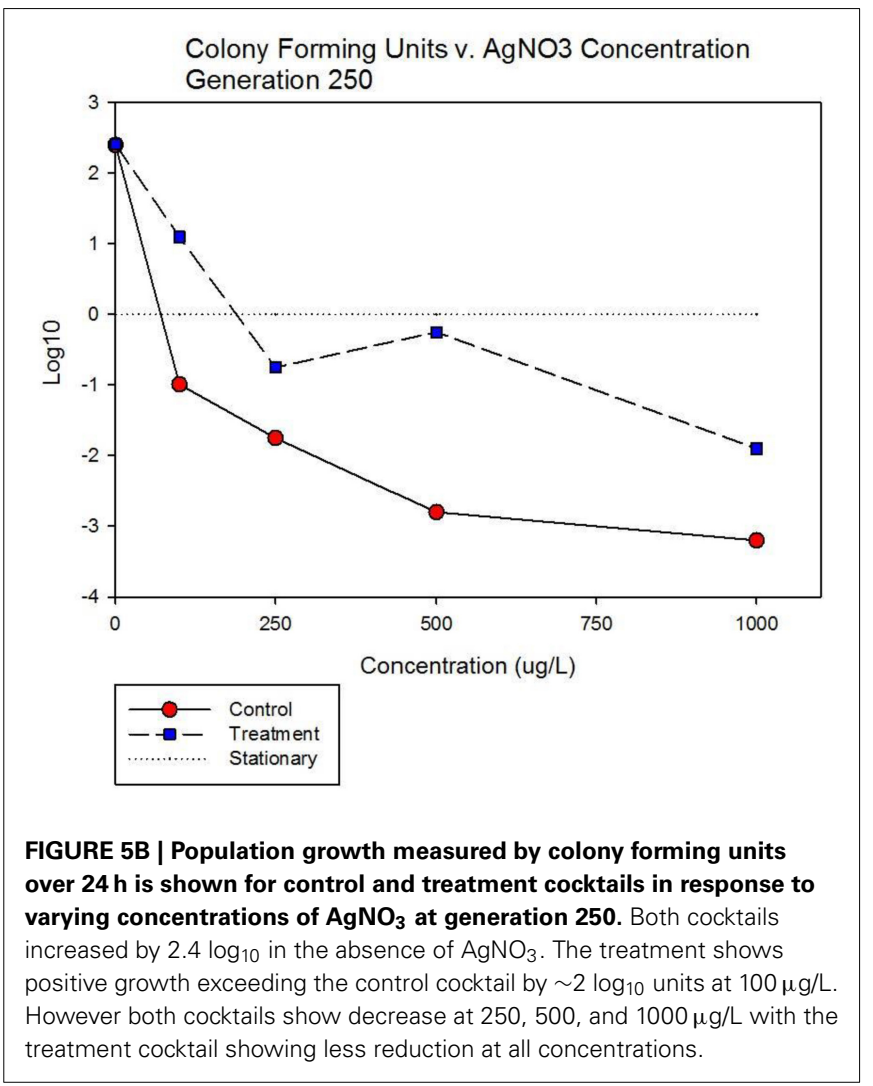


been previously documented (Nahku et al., 2011). Most notable is a $776 \mathrm{bp}$ deletion that appears in the $\mathrm{crl}$ gene at position 257,908 . This deletion was fixed (frequency $=1.00$ ) in all reads, as well as mutations at 2,173,361 ( $\Delta 2 \mathrm{bp}$ ), 3,560,455 (i1bp, G), and $4,296,380$ (i2bp, CG). The description of the genes in which each mutation occurs are found in Table 2B.

Table 3A shows the mean and SD for selected mutation frequencies for the treatment and control replicates $\left(C_{1}-C_{5}\right.$ and $\mathrm{T}_{1}-\mathrm{T}_{5}$ ) from generation 100 . These replicates were created from a common population that was grown for 11 days in standard DMB media before being established as separate populations. The control populations displayed a total of 28 putative polymorphisms, of which 5 exceeded a frequency of 0.05 . The treatment populations displayed 13 polymorphisms, of which 3 exceeded a frequency of 0.05 . The controls and treatments shared one SNP at 4,296,060 that was observed in the ancestral K-12 MG1655 strain. This SNP was reduced in frequency and ancestral SNPs 508,302 and 2,815,694 were lost in both groups. The treatment $\left(\mathrm{T}_{4}\right)$ population was the only population fixed (frequency $=1.000$ ) for a mutation in the cusS gene $(593,497, \mathrm{~T}-\mathrm{G}, \mathrm{D} 435 \mathrm{~A}, \mathrm{GAC}-\mathrm{GCC})$

Table 2A | Ancestral K-12 MG1655 Strain (Polymorphisms) summary of predicted mutations.

\begin{tabular}{lcll}
\hline Position & Mutation & Freq. & Gene \\
\hline 257,908 & $\Delta 776 \mathrm{bp}$ & 1.000 & [crl] \\
580,302 & $\mathrm{C} \rightarrow \mathrm{T}$ & 0.222 & ylcl $\leftarrow$ \\
$2,173,361$ & $\Delta 2 \mathrm{bp}$ & 1.000 & gat $\mathrm{T} \leftarrow$ \\
$2,815,694$ & $\mathrm{~A} \rightarrow \mathrm{T}$ & 0.182 & gsh $\leftarrow \leftarrow$ \\
$3,271,022$ & $\Delta 3 \mathrm{bp}$ & 0.075 & gar $\leftarrow \leftarrow$ \\
$3,560,455$ & $\mathrm{I}+\mathrm{G}$ & 1.000 & glp $R \leftarrow / \leftarrow g / p R$ \\
$4,296,060$ & $\mathrm{C} \rightarrow \mathrm{T}$ & 0.333 & gltP $\rightarrow / \leftarrow y j \mathrm{yjO}$ \\
$4,296,380$ & $\mathrm{I}+\mathrm{CG}$ & 1.000 & gltP $\rightarrow / \leftarrow y j \mathrm{yjO}$ \\
\hline
\end{tabular}

All mutations were called via breseq version 0.24rc6. In the mutation column, $D$, deletion; I, insertion; arrows indicate point mutations. In the gene column, arrows indicate the direction of the gene. If one gene name is shown the mutation is within that gene. If two gene names are shown separated by a slash, then the mutation falls within the intergenic region between those two genes. and $r p o B$ gene $(4,182,820, \mathrm{C}-\mathrm{T}, \mathrm{H} 526 \mathrm{Y}$, CAC-TAC). The cusS gene is the histidine kinase in a two-component regulatory system with $c u s R$ that senses copper ions. The $r p o B$ gene is the RNA polymerase beta subunit. The control $\left(\mathrm{C}_{4}\right)$ population also displayed the $r p o B$ mutation $(f=0.247)$. Both the control $\left(\mathrm{C}_{4}, f=0.223 ; \mathrm{C}_{5} f=1.000\right)$ and treatment $\left(\mathrm{T}_{1}, f=1.000 ; \mathrm{T}_{2}\right.$, $\left.f=1.000 ; \mathrm{T}_{3}, f=0.580 ; \mathrm{T}_{4}, f=0.000 ; \mathrm{T}_{5}, f=1.000\right)$ populations shared another mutation in $r p o B(4,182,803, \mathrm{C}-\mathrm{A}, \mathrm{P} 520 \mathrm{Q}$, CCG-CAG). Table 3B gives the annotation and description for selected polymorphic SNPs in generation 100 .

Table 4A shows the mean and SD for selected indel frequencies for the treatment and control replicates $\left(\mathrm{C}_{1}-\mathrm{C}_{5}\right.$ and $\left.\mathrm{T}_{1}-\mathrm{T}_{5}\right)$ from generation 100. The control populations displayed a total of 41 putative polymorphisms, of which 10 exceeded a frequency of 0.05 , of these 4 were ancestral and 4 shared with the treatment populations but not ancestral. The treatment populations displayed 45 polymorphisms, of which 10 exceeded a frequency of 0.05 , of which 4 were ancestral and 4 were shared with the controls but not ancestral. The ancestral 3 bp deletion at position 3,271,022 was lost in both groups. In addition, the $2 \mathrm{bp}$ deletion at 2,173,361 ( gatC) seems to be scored by breseq as either a $1 \mathrm{bp}$ or $2 \mathrm{bp}$ deletion. Two additional deletions and 1 insertion appear in both groups (positions 1,299,499; $\Delta 1,999 \mathrm{bp} ; 1,978,503 ; \Delta 776 \mathrm{bp}$; and $1,979,486$; showing an insertion element with an 4 bps duplicated at the target site (IS5) + ) $+4 \mathrm{bp})$. Table $4 \mathrm{~B}$ gives the annotation and description for selected polymorphic indels in generation 100 .

Table 5A shows the mean and SD for selected mutation frequencies for the treatment and control replicates $\left(\mathrm{C}_{1}-\mathrm{C}_{5}\right.$ and $\mathrm{T}_{1}-\mathrm{T}_{5}$ ) from generation 200. The control populations displayed a total of 86 putative polymorphisms, of which 27 exceeded a frequency of 0.05 . The treatment populations displayed 16 polymorphisms, of which 8 exceeded a frequency of 0.05 . Unlike the data from generation 100 there are no shared SNPs that were not present in the ancestral population (position 4,296,060 still remains in both.) There were 4 mutations of note in the controls. The $\mathrm{C}_{5}$ population showed a mutation in $c u s R$, a response regulator with cusS (position 594,942, E186K, GAA-AAA, $f=0.583$ ). $\mathrm{C}_{2}$ was fixed for a synonymous mutation in $c c m E$, a periplasmic heme chaperone (position 2,295,168, V71V, GTG-GTA, $f=$

Table 2B | Descriptions of predicted mutations in K-12 MG1655 Ancestral Strain.

\begin{tabular}{|c|c|c|}
\hline Gene & Annotation & Description \\
\hline [crl] & & {$[\mathrm{crl}]$} \\
\hline $\mathrm{ylcl} \leftarrow$ & $R 48 R(A G G \rightarrow A G A)$ & DUF3950 family protein, DLP12 prophage \\
\hline gatC $\leftarrow$ & pseudogene (1-2/442 nt) & $\begin{array}{l}\text { Pseudogene, galactitol-specific enzyme IIC component of PTS; transport; Transport of small } \\
\text { molecules: Carbohydrates, organic acids, alcohols; PTS system galactitol-specific enzyme IIC }\end{array}$ \\
\hline gshA $\leftarrow$ & $\mathrm{L} 249 \mathrm{H}(\mathrm{CTT} \rightarrow \mathrm{CAT})$ & Glutamate-cysteine ligase \\
\hline gark $\leftarrow$ & coding (747-749/1146 nt) & Glycerate kinase I \\
\hline glpR $\leftarrow / \leftarrow g l p R$ & intergenic $(-2 /+1)$ & $\begin{array}{l}\text { Pseudogene, DNA-binding transcriptional repressor;regulator; Energy metabolism, carbon: Anaerobic } \\
\text { respiration; repressor of the glp operon/pseudogene, DNA-binding transcriptional repressor; regulator; } \\
\text { Energy metabolism, carbon: Anaerobic respiration; repressor of the glp operon }\end{array}$ \\
\hline $\mathrm{gltP} \rightarrow / \leftarrow \mathrm{yjcO}$ & intergenic $(+266 /+376)$ & Glutamate/aspartate:proton symporter/Sel1 family TPR-like repeat protein \\
\hline $\mathrm{gltP} \rightarrow / \leftarrow \mathrm{yjcO}$ & intergenic $(+586 /+56)$ & Glutamate/aspartate:proton symporter/Sel1 family TPR-like repeat protein \\
\hline
\end{tabular}

All mutations were called via breseq version 0.24 rc6. 
Table 3A | Control and treatment single nucleotide polymorphisms (SNPs) summary of predicted mutations from generation 100.

\begin{tabular}{|c|c|c|c|c|c|c|}
\hline Position & Mutation & C Mean & C SD & T Mean & $\mathrm{T} S D$ & Gene \\
\hline 593,467 & $\mathrm{~T} \rightarrow \mathrm{G}$ & 0.000 & 0.000 & 0.200 & 0.447 & cusS $\leftarrow$ \\
\hline $1,311,179$ & $\mathrm{~T} \rightarrow \mathrm{C}$ & 0.089 & 0.199 & 0.089 & 0.199 & $\operatorname{ton} B \rightarrow$ \\
\hline $1,547,784$ & $A \rightarrow T$ & 0.015 & 0.033 & 0.015 & 0.000 & $f d n G \rightarrow$ \\
\hline $1,959,359$ & $\mathrm{G} \rightarrow \mathrm{A}$ & 0.015 & 0.033 & 0.015 & 0.033 & yecM $\leftarrow$ \\
\hline $3,440,459$ & $\mathrm{G} \rightarrow \mathrm{A}$ & 0.365 & 0.504 & 0.000 & 0.000 & $r p o A \leftarrow$ \\
\hline $3,815,808$ & $A \rightarrow C$ & 0.000 & 0.000 & 0.112 & 0.251 & $p y r E \leftarrow / \leftarrow r p h$ \\
\hline $4,182,803$ & $\mathrm{C} \rightarrow \mathrm{A}$ & 0.245 & 0.433 & 0.716 & 0.440 & $r p o B \rightarrow$ \\
\hline $4,182,820$ & $\mathrm{C} \rightarrow \mathrm{T}$ & 0.049 & 0.110 & 0.200 & 0.447 & $r p o B \rightarrow$ \\
\hline $4,186,532$ & $A \rightarrow G$ & 0.226 & 0.312 & 0.000 & 0.000 & rpoC $\rightarrow$ \\
\hline
\end{tabular}

Mean and SD for selected mutation frequencies are shown for the treatment and control replicates $\left(C_{1}-C_{5}\right.$ and $\left.T_{1}-T_{5}\right)$ from generation 100. The control populations displayed a total of 28 polymorphisms, of which 5 exceeded a frequency of 0.05 . The treatment populations displayed 13 polymorphisms, of which 3 exceeded a frequency of 0.05. Blue-shaded cells, control adaptation; orangeshaded cells, AgNP resistant adaptation; green-shaded cells are adaptations shared by both treatments, but not observed in the ancestral MG1655.

Table 3B | Description of control and treatment single nucleotide polymorphisms (SNPs) genes from generation 100.

\begin{tabular}{|c|c|c|}
\hline Gene & Annotation & Description \\
\hline cusS $\leftarrow$ & $\begin{array}{l}\mathrm{D} 435 \mathrm{~A} \\
(\mathrm{GAC} \rightarrow \mathrm{GCC})\end{array}$ & $\begin{array}{l}\text { Sensory histidine kinase in } \\
\text { two-component regulatory system with } \\
\text { CusR, senses copper ions }\end{array}$ \\
\hline $\operatorname{ton} B \rightarrow$ & $\begin{array}{l}\text { S31P } \\
(\mathrm{TCG} \rightarrow \mathrm{CCG})\end{array}$ & $\begin{array}{l}\text { Membrane spanning protein in } \\
\text { TonB-ExbB-ExbD transport complex }\end{array}$ \\
\hline$f d n G \rightarrow$ & $\begin{array}{l}\mathrm{E} 128 \mathrm{D} \\
(\mathrm{GAA} \rightarrow \mathrm{GAT})\end{array}$ & $\begin{array}{l}\text { Formate dehydrogenase- } \mathrm{N} \text {, alpha subunit, } \\
\text { nitrate-inducible }\end{array}$ \\
\hline yecM $\leftarrow$ & $\begin{array}{l}\text { A163V } \\
(\mathrm{GCG} \rightarrow \mathrm{GTG})\end{array}$ & Putative metal-binding enzyme \\
\hline rpoA $\leftarrow$ & $\begin{array}{l}\text { R191C } \\
(\text { CGT } \rightarrow \text { TGT) }\end{array}$ & RNA polymerase, alpha subunit \\
\hline $\begin{array}{l}\text { pyrE } \leftarrow / \leftarrow \\
\text { rph }\end{array}$ & $\begin{array}{l}\text { intergenic } \\
(-40 /+26)\end{array}$ & $\begin{array}{l}\text { orotate } \\
\text { phosphoribosyltransferase/ribonuclease } \\
\text { PH (defective);enzyme; Degradation of } \\
\text { RNA; RNase PH }\end{array}$ \\
\hline$r p o B \rightarrow$ & $\begin{array}{l}\text { P5200 } \\
\text { (CCG } \rightarrow \text { CAG) }\end{array}$ & RNA polymerase, beta subunit \\
\hline$r p o B \rightarrow$ & $\begin{array}{l}\mathrm{H} 526 \mathrm{Y} \\
(\mathrm{CAC} \rightarrow \mathrm{TAC})\end{array}$ & RNA polymerase, beta subunit \\
\hline rpoC $\rightarrow$ & $\begin{array}{l}\text { K395E } \\
(\mathrm{AAA} \rightarrow \mathrm{GAA})\end{array}$ & RNA polymerase, beta prime subunit \\
\hline
\end{tabular}

Blue-shaded cells, control adaptation; orange-shaded cells, AgNP resistant adaptation; green-shaded cells are adaptations shared by both treatments, but not observed in the ancestral MG1655.

1.000). There were two rpoC (RNA polymerase subunit C) mutations (position 4,186,532, K395E, AAA-GAA, $f=0.916$ in all control replicates) and (position 4,186,605, H419P, CAC-CCC, $f=0.500$ in $C_{1}$ ). Particularly notable is the rise in frequency of mutations in cusS, purL (phosphoribylsylforml-glycineamide synthetase), and $r p o B$ in the treatment populations. The cusS
Table 4A | Control and treatment structural variation from generation 100.

\begin{tabular}{|c|c|c|c|c|c|c|}
\hline Position & Mutation & C_Mean & C_SD & E_Mean & E_SD & Gene \\
\hline 380,013 & $\Delta 1 \mathrm{bp}$ & 0.000 & 0.000 & 0.049 & 0.067 & $\begin{array}{l}\text { frmR } \leftarrow \leftarrow \leftarrow \\
\text { yaiO }\end{array}$ \\
\hline 770,112 & $\Delta 3 \mathrm{bp}$ & 0.000 & 0.000 & 0.079 & 0.177 & $m n g B \rightarrow$ \\
\hline 802,819 & $\begin{array}{l}\text { IS1 (+) } \\
+9 \mathrm{bp}\end{array}$ & 0.405 & 0.492 & 0.000 & 0.000 & $y b h l \rightarrow$ \\
\hline $1,299,499$ & $\Delta 1,199 \mathrm{bp}$ & 0.600 & 0.548 & 0.200 & 0.447 & $\begin{array}{l}\text { ych } E \rightarrow I \rightarrow \\
\text { oppA }\end{array}$ \\
\hline $1,978,503$ & $\Delta 776 \mathrm{bp}$ & 0.800 & 0.447 & 0.800 & 0.447 & ins $B 1$-ins $A$ \\
\hline $1,979,486$ & $\begin{array}{l}\text { IS5 (+) } \\
+4 \mathrm{bp}\end{array}$ & 1.000 & 0.000 & 0.800 & 0.447 & $\begin{array}{l}\text { ins } A \leftarrow 1 \rightarrow \\
\text { uspC }\end{array}$ \\
\hline $2,173,361$ & $\Delta 2 \mathrm{bp}$ & 0.800 & 0.447 & 0.400 & 0.548 & gat $C \leftarrow$ \\
\hline $2,173,362$ & $\Delta 1 \mathrm{bp}$ & 0.200 & 0.447 & 0.400 & 0.548 & gatC $\leftarrow$ \\
\hline $2,375,828$ & $\begin{array}{c}\text { IS186 (+) } \\
+4 \mathrm{bp}\end{array}$ & 0.048 & 0.108 & 0.000 & 0.000 & $\operatorname{men} C \leftarrow$ \\
\hline $2,379,776$ & $\Delta 3 \mathrm{bp}$ & 0.000 & 0.000 & 0.049 & 0.110 & $\operatorname{menF} \leftarrow$ \\
\hline $3,815,801$ & $\Delta 1 \mathrm{bp}$ & 0.177 & 0.396 & 0.000 & 0.000 & $\begin{array}{l}\text { pyrE } \leftarrow / \leftarrow \\
\text { rph }\end{array}$ \\
\hline
\end{tabular}

Mean and SD for selected indel frequencies are shown for the treatment and control replicates $\left(C_{1}-C_{5}\right.$ and $\left.T_{1}-T_{5}\right)$ from generation 100. The control populations displayed a total of 41 polymorphisms, of which 10 exceeded a frequency of 0.05 , of these 3 were ancestral and five shared with the treatment populations but not ancestral. The treatment populations displayed 45 polymorphisms, of which 10 exceeded a frequency of 0.05, of which 3 were ancestral and 5 were shared with the controls but not ancestral. Blue-shaded cells, control adaptation; orange-shaded cells, AgNP resistant adaptation; green-shaded cells are adaptations shared by both treatments, but not observed in the ancestral MG1655.

mutation at position 543,459 is at $f=0.803$ in $\mathrm{T}_{1}$ and at position 593,467 is at $f=1.000$ for all five replicates. The purL mutation (position 2,694,130) is fixed $(f=1.000)$ in all but $\mathrm{T}_{3}$ and the rpoB mutation $(4,182,820)$ is fixed in all five treatment replicates. These mutations are not found in the control populations. This result is particularly interesting in that the $r p o B$ mutation $(4,182,820)$ was rare in the controls in generation 100 at $f=0.049$. In addition, the $r p o B$ mutation at position $4,182,803$ that was shared by both groups in generation 100 was not detected in either in generation 200. Table 5B gives the annotation and description for selected polymorphic SNPs in generation 200 .

Table 6A shows the mean and SD for selected indel frequencies for the control and treatment replicates $\left(C_{1}-C_{5}\right.$ and $\left.T_{1}-T_{5}\right)$ from generation 200. The control populations displayed a total of 63 putative polymorphisms, of which 9 exceeded a frequency of 0.05 , of these 3 were ancestral and 5 were shared with the treatment populations but were not ancestral. The treatment populations displayed 34 polymorphisms, of which 12 exceeded a frequency of 0.05 , of which 3 were ancestral and 5 shared with the control populations but not ancestral. The one indel in the control populations was at very low frequency (position $2,552,098,15$-bp insertion in $y p e A$, putative acyl-CoA transferase.). However, the treatment populations had 4 indels of significance (position 2,648,163, $\Delta 7 \mathrm{bp}, y f h M$, a periplasmic inner 
Table 4B | Description of control and treatment indels from generation 100.

\begin{tabular}{|c|c|c|}
\hline Gene & Annotation & Description \\
\hline $\mathrm{frm} R \leftarrow / \leftarrow$ yaiO & $\begin{array}{l}\text { intergenic } \\
(-132 /+56)\end{array}$ & $\begin{array}{l}\text { Regulator protein that represses } \\
\text { frmRAB operon/outer } \\
\text { membrane protein }\end{array}$ \\
\hline$m n g B \rightarrow$ & $\begin{array}{l}\text { coding } \\
(2135-2137 / 2634 \mathrm{nt})\end{array}$ & Alpha-mannosidase \\
\hline$y b h l \rightarrow$ & $\begin{array}{l}\text { coding } \\
\text { (933-941/1434 nt) }\end{array}$ & Putative transporter \\
\hline$y c h E \rightarrow I \rightarrow$ oppA & $\begin{array}{l}\text { intergenic } \\
(+254 /-485)\end{array}$ & $\begin{array}{l}\text { UPF0056 family inner } \\
\text { membrane protein/oligopeptide } \\
\text { transporter subunit }\end{array}$ \\
\hline ins $B 1-$ ins $A$ & & ins $B 1$, ins $A$ \\
\hline ins $A \leftarrow / \rightarrow$ usp $C$ & $\begin{array}{l}\text { intergenic } \\
(-271 /-264)\end{array}$ & $\begin{array}{l}\text { IS1 repressor TnpA/universal } \\
\text { stress protein }\end{array}$ \\
\hline gat $C \leftarrow$ & $\begin{array}{l}\text { pseudogene }(1-2 / 442 \\
n t)\end{array}$ & $\begin{array}{l}\text { Pseudogene, galactitol-specific } \\
\text { enzyme IIC component of PTS; } \\
\text { transport; Transport of small } \\
\text { molecules: Carbohydrates, } \\
\text { organic acids, alcohols; PTS } \\
\text { system galactitol-specific } \\
\text { enzyme IIC }\end{array}$ \\
\hline gat $C \leftarrow$ & $\begin{array}{l}\text { pseudogene }(1 / 442 \\
\text { nt) }\end{array}$ & $\begin{array}{l}\text { Pseudogene, galactitol-specific } \\
\text { enzyme IIC component of PTS; } \\
\text { transport; Transport of small } \\
\text { molecules: Carbohydrates, } \\
\text { organic acids, alcohols; PTS } \\
\text { system galactitol-specific } \\
\text { enzyme IIC }\end{array}$ \\
\hline $\operatorname{men} C \leftarrow$ & $\begin{array}{l}\text { coding (132-135/963 } \\
\text { nt) }\end{array}$ & $\begin{array}{l}\text { O-succinylbenzoyl-CoA } \\
\text { synthase }\end{array}$ \\
\hline menF $\leftarrow$ & $\begin{array}{l}\text { coding } \\
\text { (866-868/1296 nt) }\end{array}$ & Isochorismate synthase 2 \\
\hline pyrE $\leftarrow / \leftarrow r p h$ & intergenic $(-33 /+33)$ & $\begin{array}{l}\text { Orotate phosphoribosyltrans- } \\
\text { ferase/ribonuclease PH } \\
\text { (defective);enzyme; Degradation } \\
\text { of RNA; RNase PH }\end{array}$ \\
\hline
\end{tabular}

Blue-shaded cells, control adaptation; orange-shaded cells, AgNP resistant adaptation; green cells are adaptations shared by both treatments, but not observed in the ancestral MG1655.

membrane-anchored lipoprotein, $\mathrm{T}_{3}, f=0.498$ ) and three different mutations in $\operatorname{omp} R$, response regulator in two-component regulatory system with env $Z$, (position 3,536,264, $\Delta 1 \mathrm{bp}, \mathrm{T}_{1}$, $f=1.000$; position $3,536,342,12 \mathrm{bp}, \mathrm{T}_{3}, f=0.947$; and position $3,536,570$, IS3 $(-)+4 \mathrm{bp}::+$ TCA, $\left.\mathrm{T}_{5}, f=1.000\right)$. Table 6B gives the annotation and description for selected polymorphic indels in generation 200 .

\section{DISCUSSION}

The purpose of this study was to determine how rapidly and by what kinds of genomic changes AgNP resistance could evolve in a relatively naïve bacterium, E. coli K-12 MG1655. Here we have shown this bacterium can rapidly evolve resistance to AgNPs. By generation 162 we observed phenotypic evidence that the AgNP resistance of the treatment populations was greater than that of
Table 5A | Control and treatment single nucleotide polymorphisms (SNPs) from generation 200.

\begin{tabular}{|c|c|c|c|c|c|c|}
\hline Position & Mutation & C Mean & $S D$ & T Mean & $S D$ & Gene \\
\hline $31,593^{*}$ & $A \rightarrow G$ & 0.075 & 0.169 & 0.000 & 0.000 & $\operatorname{car} B \rightarrow$ \\
\hline 480,975 & $\mathrm{C} \rightarrow \mathrm{T}$ & 0.000 & 0.000 & 0.065 & 0.144 & tom $B \leftarrow 1 \leftarrow a c r B$ \\
\hline 533,893 & $\mathrm{C} \rightarrow \mathrm{A}$ & 0.000 & 0.000 & 0.200 & 0.447 & allR $\rightarrow / \rightarrow g c l$ \\
\hline 593,459 & $\mathrm{G} \rightarrow \mathrm{A}$ & 0.000 & 0.000 & 0.161 & 0.359 & cusS $\leftarrow$ \\
\hline 593,467 & $\mathrm{~T} \rightarrow \mathrm{G}$ & 0.000 & 0.000 & 1.000 & 0.000 & cusS $\leftarrow$ \\
\hline 594,942 & $\mathrm{C} \rightarrow \mathrm{T}$ & 0.117 & 0.261 & 0.000 & 0.000 & cusR $\leftarrow$ \\
\hline $2,158,055$ & $\mathrm{G} \rightarrow \mathrm{C}$ & 0.053 & 0.118 & 0.000 & 0.000 & $m d t B \rightarrow$ \\
\hline $2,222,961$ & $\mathrm{G} \rightarrow \mathrm{A}$ & 0.069 & 0.153 & 0.000 & 0.000 & $d l d \rightarrow$ \\
\hline $2,295,168$ & $\mathrm{C} \rightarrow \mathrm{T}$ & 0.200 & 0.447 & 0.000 & 0.000 & $c c m E \leftarrow$ \\
\hline $2,494,491$ & $\mathrm{G} \rightarrow \mathrm{T}$ & 0.000 & 0.000 & 0.152 & 0.339 & $y f d X \leftarrow l \rightarrow y p d l$ \\
\hline $2,694,130$ & $\mathrm{G} \rightarrow \mathrm{T}$ & 0.000 & 0.000 & 0.800 & 0.447 & purL $\leftarrow$ \\
\hline $3,416,100 *$ & $\mathrm{~T} \rightarrow \mathrm{C}$ & 0.098 & 0.220 & 0.000 & 0.000 & $\mathrm{acr} F \rightarrow$ \\
\hline $3,473,242$ & $\mathrm{C} \rightarrow \mathrm{G}$ & 0.050 & 0.112 & 0.000 & 0.000 & fus $A \leftarrow$ \\
\hline $3,473,371$ & $\mathrm{~T} \rightarrow \mathrm{G}$ & 0.057 & 0.128 & 0.000 & 0.000 & fus $A \leftarrow$ \\
\hline $3,473,386$ & $A \rightarrow C$ & 0.055 & 0.122 & 0.000 & 0.000 & fus $A \leftarrow$ \\
\hline $4,182,820$ & $\mathrm{C} \rightarrow \mathrm{T}$ & 0.000 & 0.000 & 1.000 & 0.000 & $r p o B \rightarrow$ \\
\hline $4,186,532$ & $A \rightarrow G$ & 0.916 & 0.189 & 0.000 & 0.000 & rpoC $\rightarrow$ \\
\hline $4,186,605$ & $A \rightarrow C$ & 0.100 & 0.224 & 0.000 & 0.000 & rpoC $\rightarrow$ \\
\hline
\end{tabular}

Mean and SD for selected mutation frequencies are shown for the treatment and control replicates $\left(C_{1}-C_{5}\right.$ and $\left.T_{1}-T_{5}\right)$ from generation 200. The control populations displayed a total of 86 polymorphisms, of which 27 exceeded a frequency of 0.05 . The treatment populations displayed 16 polymorphisms, of which 8 exceeded a frequency of 0.05. Blue-shaded cells, control adaptation; red-shaded cells, AgNP resistant adaptation.

${ }^{*}$ Additional SNPs in carB, 31,599; 602; 621; 644; and 650 ranged from 0.0740.085 and additional SNPs in acrF were $3,416,107 ; 118 ; 121 ; 124 ; 136 ; 148 ; 151$; 158; 161; and 163 ranged from $0.053-0.098$.

the controls. By generation 250 we show definite resistance to $10 \mathrm{~nm}$ citrate-coated AgNPs as well as to ionic $\mathrm{Ag}^{+}\left(\mathrm{AgNO}_{3}\right)$. Subsequent selection actually increased both $\mathrm{AgNP}$ and $\mathrm{AgNO}_{3}$ treatment population resistance by generation 300 to between 4.66 and 1.40 times the MIC of the controls to various sorts of AgNP, but also to greater than 26 times the $\mathrm{AgNO}_{3}$ resistance of the controls (Graves, 2014). The genomic analysis demonstrates that resistance alleles were already accumulating in the AgNP resistant populations by generation 100. The increase in resistance we have observed does not seem to be the result of major genomic changes. Rather, by generation 200, mutations in four genes had swept to fixation (or nearly so) in all or some of the treatment populations. Not surprisingly, a mutation occurred in a bacterial system that is known to play a role in regulating heavy metal concentration in the intercellular environment (cusS; D435A (GAC $\rightarrow$ GCC) a non-synonymous point mutation at position 593,467; this is a sensory histidine kinase from the $\operatorname{ompR}$ family that is in a two-component regulatory system with CusR, that senses copper ions). This mutation was fixed in all five populations. Data from generation 100 suggests that it originated in $\mathrm{T}_{4}$. A second mutation in cusS (position $593,459, \mathrm{R} 438 \mathrm{C}, \mathrm{CGC}-\mathrm{TGC}, f=0.803$ ) was also scored in $\mathrm{T}_{1}$. (Lok et al., 2008) as well as (Gudipathy and McEvoy, 2014) summarize the role of cusS in silver resistance. CusS is part of 
Table 5B | Description of control and treatment SNPs from generation 100.

\begin{tabular}{|c|c|c|}
\hline Gene & Annotation & Description \\
\hline $\operatorname{car} B \rightarrow$ & $\begin{array}{l}\mathrm{K} 259 \mathrm{~K} \\
(\mathrm{AAA} \rightarrow \mathrm{AAG})\end{array}$ & $\begin{array}{l}\text { Carbamoyl-phosphate synthase large } \\
\text { subunit }\end{array}$ \\
\hline $\begin{array}{l}\operatorname{tom} B \leftarrow / \leftarrow \\
\operatorname{acr} B\end{array}$ & $\begin{array}{l}\text { Intergenic } \\
(-267 /+279)\end{array}$ & $\begin{array}{l}\text { Hha toxicity attenuator; conjugation-related } \\
\text { protein/multidrug efflux system protein }\end{array}$ \\
\hline allR $\rightarrow / \rightarrow g c l$ & $\begin{array}{l}\text { Intergenic } \\
(+67 /-23)\end{array}$ & $\begin{array}{l}\text { Transcriptional repressor of all and gcl } \\
\text { operons; glyoxylate-induced/glyoxylate } \\
\text { carboligase }\end{array}$ \\
\hline cusS $\leftarrow$ & $\begin{array}{l}\mathrm{R} 438 \mathrm{C} \\
(\mathrm{CGC} \rightarrow \mathrm{TGC})\end{array}$ & $\begin{array}{l}\text { sensory histidine kinase in two-component } \\
\text { regulatory system with CusR, senses } \\
\text { copper ions }\end{array}$ \\
\hline cusS $\leftarrow$ & $\begin{array}{l}\mathrm{D} 435 \mathrm{~A} \\
(\mathrm{GAC} \rightarrow \mathrm{GCC})\end{array}$ & $\begin{array}{l}\text { Sensory histidine kinase in two-component } \\
\text { regulatory system with CusR, senses } \\
\text { copper ions }\end{array}$ \\
\hline cus $R \leftarrow$ & $\begin{array}{l}\text { E168K } \\
(\mathrm{GAA} \rightarrow \mathrm{AAA})\end{array}$ & $\begin{array}{l}\text { Response regulator in two-component } \\
\text { regulatory system with CusS }\end{array}$ \\
\hline$m d t B \rightarrow$ & $\begin{array}{l}\text { V931V } \\
\text { (GTG } \rightarrow \text { GTC) }\end{array}$ & Multidrug efflux system, subunit B \\
\hline$d l d \rightarrow$ & $\begin{array}{l}\mathrm{K} 259 \mathrm{~K} \\
(\mathrm{AAG} \rightarrow \mathrm{AAA})\end{array}$ & $\begin{array}{l}\text { D-lactate dehydrogenase, FAD-binding, } \\
\mathrm{NADH} \text { independent }\end{array}$ \\
\hline$c c m E \leftarrow$ & $\begin{array}{l}\text { V71V } \\
(\text { GTG } \rightarrow \text { GTA) }\end{array}$ & Periplasmic heme chaperone \\
\hline $\begin{array}{l}\text { yfd } X \leftarrow 1 \rightarrow \\
\text { ypdl }\end{array}$ & $\begin{array}{l}\text { intergenic } \\
(-89 /-207)\end{array}$ & $\begin{array}{l}\text { Uncharacterized protein/putative lipoprotein } \\
\text { involved in colanic acid biosynthesis }\end{array}$ \\
\hline purL $\leftarrow$ & $\begin{array}{l}\text { R472S } \\
(\mathrm{CGC} \rightarrow \mathrm{AGC})\end{array}$ & $\begin{array}{l}\text { Phosphoribosylformyl-glycineamide } \\
\text { synthetase }\end{array}$ \\
\hline$a c r F \rightarrow$ & $\begin{array}{l}\text { Y356Y } \\
\text { (TAT } \rightarrow \text { TAC) }\end{array}$ & Multidrug efflux system protein \\
\hline fus $A \leftarrow$ & $\begin{array}{l}\mathrm{G} 91 \mathrm{G} \\
(\mathrm{GGG} \rightarrow \mathrm{GGC})\end{array}$ & $\begin{array}{l}\text { Protein chain elongation factor EF-G, } \\
\text { GTP-binding }\end{array}$ \\
\hline fus $A \leftarrow$ & $\begin{array}{l}\mathrm{A} 48 \mathrm{~A} \\
(\mathrm{GCA} \rightarrow \mathrm{GCC})\end{array}$ & $\begin{array}{l}\text { Protein chain elongation factor EF-G, } \\
\text { GTP-binding }\end{array}$ \\
\hline fus $A \leftarrow$ & $\begin{array}{l}\text { V43V } \\
(\mathrm{GTT} \rightarrow \mathrm{GTG})\end{array}$ & $\begin{array}{l}\text { Protein chain elongation factor EF-G, } \\
\text { GTP-binding }\end{array}$ \\
\hline$r p o B \rightarrow$ & $\begin{array}{l}\mathrm{H} 526 \mathrm{Y} \\
(\mathrm{CAC} \rightarrow \mathrm{TAC})\end{array}$ & RNA polymerase, beta subunit \\
\hline rpoC $\rightarrow$ & $\begin{array}{l}\text { K395E } \\
(\mathrm{AAA} \rightarrow \mathrm{GAA})\end{array}$ & RNA polymerase, beta prime subunit \\
\hline rpoC $\rightarrow$ & $\begin{array}{l}\mathrm{H} 419 \mathrm{P} \\
(\mathrm{CAC} \rightarrow \mathrm{CCC})\end{array}$ & RNA polymerase, beta prime subunit \\
\hline
\end{tabular}

Blue-shaded cells, control adaptation; red-shaded cells, AgNP resistant adaptation.

the two-component sensor/responder system located next to the CusCFBA efflux system in the E. coli genome. CusCFBA is analogous to (and shares high sequence homology with) SilCFBA the plasmid-encoded silver resistance mechanism of Salmonella typhimurium. CusS is a sensor that is a membrane associated gene histidine kinase. It is autophosphorylated upon external stimuli sensed in the periplasmic domain (in this case, $\mathrm{Ag}^{+}$or $\mathrm{Cu}^{2+}$ stress). The cus $S$ gene is highly conserved in other E. coli strains, as evidenced by BLAST search using the ancestral E. coli K-12 MG1655 cusS sequence. The search returned cusS matches from 134 E. coli and Shigella strains that had $91-100 \%$ identity to the MG1655 sequence.
Table 6A | Control and treatment structural variation from generation 200.

\begin{tabular}{|c|c|c|c|c|c|c|}
\hline Position & Mutation & C Mean & C SD & T Mean & T SD & Gene \\
\hline $1,299,499$ & $\Delta 1,199 \mathrm{bp}$ & 0.600 & 0.548 & 0.400 & 0.548 & $\begin{array}{l}\text { ych } E \rightarrow I \rightarrow \\
\text { oppA }\end{array}$ \\
\hline $1,978,503$ & $\Delta 776 \mathrm{bp}$ & 0.600 & 0.548 & 0.800 & 0.447 & insB 1-insA \\
\hline $1,979,486$ & IS5 $(+)+4$ bp & 1.000 & 0.000 & 0.800 & 0.447 & $\begin{array}{l}\operatorname{ins} A \leftarrow 1 \rightarrow \\
\text { uspC }\end{array}$ \\
\hline $2,173,361$ & $\Delta 2 \mathrm{bp}$ & 0.800 & 0.447 & 0.600 & 0.548 & gat $C \leftarrow$ \\
\hline $2,173,361$ & $\Delta 1 \mathrm{bp}$ & 0.187 & 0.419 & 0.400 & 0.548 & gat $C \leftarrow$ \\
\hline $2,552,098$ & $+15 b p$ & 0.072 & 0.161 & 0.000 & 0.000 & уре $A \leftarrow$ \\
\hline $2,648,163$ & $\Delta 7 \mathrm{bp}$ & 0.000 & 0.000 & 0.100 & 0.223 & $y f h M \leftarrow$ \\
\hline $3,536,264$ & $\Delta 1 \mathrm{bp}$ & 0.000 & 0.000 & 0.200 & 0.447 & $o m p R \leftarrow$ \\
\hline $3,536,342$ & $\Delta 12 \mathrm{bp}$ & 0.000 & 0.000 & 0.189 & 0.424 & ompR $\leftarrow$ \\
\hline $3,536,570$ & $\begin{array}{l}\text { IS3 }(-)+4 \text { bp:: } \\
+ \text { TCA }\end{array}$ & 0.000 & 0.000 & 0.200 & 0.447 & $o m p R \leftarrow$ \\
\hline
\end{tabular}

Mean and SD for selected indel frequencies are shown for the treatment and control replicates $\left(C_{1}-C_{5}\right.$ and $\left.T_{1}-T_{5}\right)$ from generation 200. The control populations displayed a total of 63 polymorphisms, of which 9 exceeded a frequency of 0.05 , of these 3 were ancestral and 5 were shared with the treatment populations but were not ancestral. The treatment populations displayed 34 polymorphisms, of which 12 exceeded a frequency of 0.05 , of which 3 were ancestral and 5 shared with the control populations but not ancestral. Blueshaded cells, control adaptation; red-shaded cells, AgNP resistant adaptation; green-shaded cells are adaptations shared by both treatments, but not observed in the ancestral MG1655.

The second mutation was in purL (R472S (CGC $\rightarrow$ AGC), a non-synonymous point mutation at position 2,694,130; phosphoribosylformyl-glycineamide synthetase). This gene catalyzes conversion of $5^{\prime}$-phosphoribosylformylglycinamide (FGAR) to formylglycinamide in the presence of glutamine and ATP for de novo purine nucleotide biosynthesis (Sampei and Mizobuchi, 1989). BLAST search confirmed that the K-12 MG1655 purL consensus sequence was highly conserved across E. coli strains, 100 matches showed from $98-100 \%$ identity. Again, the AgNP resistant mutation was not found in any of the E. coli or Shigella spp. sequences uncovered by the search.

The third mutation was in RNA polymerase beta subunit, $r p o B,(\mathrm{H} 526 \mathrm{Y}$ (CAC $\rightarrow$ TAC) a non-synonymous point mutation at position 4,182,820; RNA polymerase, beta subunit). It was fixed in all treatment populations, and also was first observed in $\mathrm{C}_{4}$ $(f=0.223)$ and $\mathrm{T}_{4}(f=1.000)$ in generation 100. By generation 200, $C_{4}$ had lost the mutation and it had become fixed in all treatment populations. Adaptive mutations in RNA polymerase are often found in E. coli evolution experiments (Conrad et al., 2011), as altering its activity can have large impacts on global gene expression patterns (Conrad et al., 2010).

The adaptive character of both of the cusS and rpoB are indicated by the fact that they are non-synonymous mutations that occur within active sites of their enzymes. The cusS mutation is found in the histidine-kinase, DNA gyrase B, and HSP90-like ATPase domain of the protein (Li et al., 2008; ecogene ${ }^{1}$ ). The

\footnotetext{
${ }^{1}$ http://www.kegg.jp/ssdb-bin/ssdb_motif?kid=eco:b0570.
} 
Table 6B | Description of control and treatment indels from generation 200.

\begin{tabular}{|c|c|c|}
\hline Gene & Annotation & Description \\
\hline$y c h E \rightarrow / \rightarrow o p p A$ & $\begin{array}{l}\text { Intergenic } \\
(+254 /-485)\end{array}$ & $\begin{array}{l}\text { UPF0056 family inner membrane } \\
\text { protein/oligopeptide transporter } \\
\text { subunit }\end{array}$ \\
\hline insB 1 -ins $A$ & & insB1, ins $A$ \\
\hline $\operatorname{ins} A \leftarrow 1 \rightarrow$ uspC & $\begin{array}{l}\text { Intergenic } \\
(-271 /-264)\end{array}$ & $\begin{array}{l}\text { IS1 repressor TnpA/universal } \\
\text { stress protein }\end{array}$ \\
\hline gat $C \leftarrow$ & $\begin{array}{l}\text { Pseudogene } \\
(1-2 / 442 \mathrm{nt})\end{array}$ & $\begin{array}{l}\text { Pseudogene, galactitol-specific } \\
\text { enzyme IIC component of } \\
\text { PTS;transport; Transport of small } \\
\text { molecules: Carbohydrates, } \\
\text { organic acids, alcohols; PTS } \\
\text { system galactitol-specific enzyme } \\
\text { IIC }\end{array}$ \\
\hline gat $C \leftarrow$ & $\begin{array}{l}\text { pseudogene } \\
\text { (2/442 nt) }\end{array}$ & $\begin{array}{l}\text { Pseudogene, galactitol-specific } \\
\text { enzyme IIC component of } \\
\text { PTS; transport; Transport of small } \\
\text { molecules: Carbohydrates, } \\
\text { organic acids, alcohols; PTS } \\
\text { system galactitol-specific enzyme } \\
\text { IIC }\end{array}$ \\
\hline уре $A \leftarrow$ & $\begin{array}{l}\text { coding } \\
\text { (41/426 nt) }\end{array}$ & Putative acyl-CoA transferase \\
\hline yfhM $\leftarrow$ & $\begin{array}{l}\text { coding (4119- } \\
4125 / 4962 \\
\text { nt) }\end{array}$ & $\begin{array}{l}\text { Bacterial alpha2-macroglobulin } \\
\text { colonization factor ECAM; } \\
\text { anti-host protease defense factor; } \\
\text { periplasmic inner } \\
\text { membrane-anchored lipoprotein }\end{array}$ \\
\hline $\mathrm{omp} R \leftarrow$ & $\begin{array}{l}\text { coding } \\
\text { (321/720 nt) }\end{array}$ & $\begin{array}{l}\text { Response regulator in } \\
\text { two-component regulatory } \\
\text { system with EnvZ }\end{array}$ \\
\hline$o m p R \leftarrow$ & $\begin{array}{l}\text { coding } \\
(232-243 / 720 \\
\text { nt) }\end{array}$ & $\begin{array}{l}\text { Response regulator in } \\
\text { two-component regulatory } \\
\text { system with EnvZ }\end{array}$ \\
\hline $\mathrm{ompR} \leftarrow$ & $\begin{array}{l}\text { coding } \\
(12-15 / 720 \mathrm{nt})\end{array}$ & $\begin{array}{l}\text { Response regulator in } \\
\text { two-component regulatory } \\
\text { system with EnvZ }\end{array}$ \\
\hline
\end{tabular}

Blue-shaded cells, control adaptation; red-shaded cells, AgNP resistant adaptation; green-shaded cells are adaptations shared by both treatments, but not observed in the ancestral MG1655.

$r p o B$ mutation occurs within the Rpb2 domain 3 site of the RNA polymerase B (Cramer et al., 2001; ecogene ${ }^{2}$ ). The purL mutation occurs prior to the enzyme's active sites (257-389; 432-589; and 822-966; Li et al., 1999; ecogene ${ }^{3}$ ). In generation 100, the $r p o B$ mutation was also at high frequency in $\mathrm{C}_{4}$ at $f=0.247$. This might indicate that this mutation was a general adaptation that was useful in both the non- $\mathrm{Ag}^{+}$and $\mathrm{Ag}^{+}$environments. However, by generation 200 the $\mathrm{C}_{4}$ population had lost the $r p o B$ mutation, while it had swept to fixation in the treatment populations. Thus it is possible that the benefit that $r p o B$ gave was greater for the treatments as compared to the controls. The best way to

\footnotetext{
${ }^{2}$ http://www.kegg.jp/ssdb-bin/ssdb_motif?kid=eco:b3987.
}

${ }^{3}$ http://www.kegg.jp/ssdb-bin/ssdb_motif?kid=eco:b2557. determine if there is any specific $\mathrm{Ag}^{+}$resistance derived from any of these mutations will be to do allelic exchange experiments that place these mutations into the ancestral bacterium and determine if either individually or together they improve AgNP resistance.

In addition to the point mutations observed in AgNP populations in generation 200, at least three of the indels scored may be of particular significance. Three indels (position 3,536,264, $\Delta$ lbp, ompR, $\mathrm{T}_{1}, f=1.000$; position 3,536,342, $\Delta 12 \mathrm{bp}$, ompR, $\mathrm{T}_{2}, f=0.947$; position 3,536,570, IS3(-) +4bp::TCA, ompR, $\mathrm{T}_{5}$, $f=1.000$ ) were scored. OmpR is a DNA binding protein that is involved in regulating gene networks (Quinn et al., 2014). While its sequence is highly conserved in gram negative bacteria, the collection of genes that it's governs can vary widely. Rhee et al. (2008) have shown that OmpR protein has only moderate specificity for its DNA sites and that this allows new specificity to evolve via only a few mutational steps. Furthermore, OmpR has the potential to respond to more than one environmental signal. In Salmonella Typhimurium it responds to acid stress (Quinn et al., 2014). This bacterium is also of great interest with regards to silver resistance, as silver resistant strains have been isolated from both silver mines and clinical environments (McHugh et al., 1975). Given our results we suggest that these indels in the ompR sequence of our AgNP resistant populations may be producing an $\mathrm{OmpR}$ protein that plays a new role in regulating responses to $\mathrm{Ag}^{+}$resistance.

\section{SELECTIVE SWEEPS}

The design of this experiment is incapable of addressing whether the increase in AgNP resistance mutations occurred by hard or soft sweeps. We began the experiment by sampling the ancestral ATCC 47076 strain of K-12 MG1655 and growing up a stock culture for 11 days $(\sim 71$ generations). During this time mutations began to accumulate in the stock culture that were not present in the ancestral strain. The control and treatment replicates were sampled from the stock culture and thus share genetic diversity and recent common ancestry with each other $\left(\mathrm{T}_{1}\right.$ sampled from $\mathrm{C}_{1}, \mathrm{~T}_{2}$ sampled from $\mathrm{C}_{2}$, etc.). For the first 100 generations of the experiment, each of the replicate populations evolved separately from all others. In the control replicates at generation 52/56 scored SNP/indel mutations (not ancestral) were unique to a specific replicate and most were rare. For the treatment populations, 43/46 scored SNP/indel mutations (not ancestral) were unique to a specific population, however two of interest were already at very high frequency ( $\mathrm{T}_{4}$, position 597,467, cusS, $f=1.000$ and in $\mathrm{T}_{1}$, $\mathrm{T}_{2}, \mathrm{~T}_{3}, \mathrm{~T}_{5}$, position $4,183,803, r p o B, f=1.000,1.000,0.580$, and $1.000 ; \mathrm{T}_{4}$, position $\left.4,182,820, \operatorname{rpoB}, f=1.000\right)$. The rpoB mutations were shared with the controls $\left(\mathrm{C}_{4}, \mathrm{C}_{5}\right.$, position $4,183,803$, $r p o B, f=0.223,1.000$ and $C_{3}$, position 4,182,820, rpoB, $f=$ $0.247)$. Given that the control and treatment populations were derived from a stock population that evolved for 71 generations, it is possible that all of the polymorphisms were established in the stock population before the AgNP resistance selection began.

After generation 141 the treatment populations were cocktailed to rescue the poor preforming replicates. This means that cells from the $\mathrm{T}_{4}$ replicate were spread into the other populations. By generation 200, the control populations had 138/143 putative $\mathrm{SNP} /$ indel mutations that were unique to a specific population, 
and the treatment populations had 39/42 SNP/indel putative mutations that were unique to a specific population. The later result is somewhat startling, given the mixing of the treatments populations in generation 141. By generation 200, the cusS and rpoB mutations (first scored in $\mathrm{T}_{4}$ ) had swept to fixation in all treatment populations, the purL mutation was fixed in 4/5 treatment populations (but had not been detected in generation 100). The most significant AgNP resistance associated indels (ompR) were also unique to the treatment populations.

\section{FUTURE DIRECTIONS}

We are currently engaged in research to address the evolvability of $\mathrm{AgNp}$ (and general $\mathrm{Ag}^{+}$ion resistance) resistance in E. coli K-12 MG1655. Our AgNP resistant populations were carried to generation 305. At the time of this writing, sequencing of the generation 300 controls and treatments is underway. We have shown that AgNP and AgNO3 resistance has increased in these populations. Our goal will be to determine if the genomic variants we scored in generation 200, as well as new variants that may have accumulated in the treatment replicates are involved in bringing about this increased resistance. We have also selected 18 new replicate populations for resistance to $\mathrm{AgNO}_{3}$. These populations were all founded by single colonies derived from the ancestral K12 MG1655 and were never mixed. This will allow us to address questions concerning mutational history of individual replicates as well as to determine if evolutionary convergence occurs with regards to $\mathrm{AgNO}_{3}$ resistance. We also wish to test whether and which genomic variants scored in the AgNP resistance studies reappear in the $\mathrm{AgNO}_{3}$ resistance replicates. Ultimately for definitive proof of the contribution of each mutation we score to AgNP or $\mathrm{Ag}^{+}$resistance we will need to perform allelic exchange experiments. This give us direct evidence that an individual mutation or a set of mutations improve AgNP or $\mathrm{Ag}^{+}$ion resistance in the genetic background of our original E. coli K-12 MG1655 bacterium.

\section{CONCLUSION}

Experimental evolution was able to rapidly evolve resistance to $10 \mathrm{~nm}$ citrate-coated AgNPs in a relatively naïve bacterium, E. coli K-12 MG1655. Resistance required relatively few mutational steps. Thus, these therapies must contend not only with microbes receiving heavy resistance genes via horizontal transfer but also with AgNP resistance readily arising from de novo mutations in existing genes. This outcome does not bode well for the sustained use of AgNPs as "miracle" antimicrobials.

\section{ACKNOWLEDGMENTS}

The following individuals have given care to the experiments from my laboratory described in this paper: Divya Iyer, and Mubin Tarannum. Dr. Richard Lenski gave helpful comments concerning our original experimental design, and Dr. Daniel Deatherage provided assistance with breseq. This work was funded via support from the Joint School of Nanoscience \& Nanoengineering, North Carolina A\&T State University and UNC Greensboro. This material is based in part upon work supported by the National Science Foundation under Cooperative Agreement No. DBI-0939454
(BEACON). Any opinions, findings, and conclusions or recommendations expressed in this material are those of the author(s) and do not necessarily reflect the views of the National Science Foundation.

\section{REFERENCES}

Barrick, J. E., Yu, D. S., Yoon, S. H., Jeong, H., Oh, T. K., Schneider, D., et al. (2009). Genome evolution and adaptation in a long-term experiment with Escherichia coli. Nature 461, 1243-1249. doi: 10.1038/nature08480

Conrad, T. M., Frazier, M., Joyce, A. R., Cho, B.-K, Knight, E. M., Lewis, N. E., et al (2010). RNA polymerase mutants found through adaptive evolution reprogram Escherichia coli for optimal growth in minimal media. Proc. Natl. Acad. Sci. U.S.A.107, 20500-20505. doi: 10.1073/pnas.0911253107

Conrad, T. M., Lewis, N. E., and Palsson, B. O. (2011). Microbial laboratory evolution in the era of genome-scale science. Mol. Syst. Biol. 7:509. doi: $10.1038 / \mathrm{msb} .2011 .42$

Cramer, P., Bushnell, D. A., and Kornberg, R. D. (2001). Structural basis of transcription: RNA polymerase II at 2.8 angstrom resolution. Science 292, 1863-1876. doi: 10.1126/science.1059493

Deatherage, D. E., and Barrick, J. E. (2014). Identification of mutations in laboratory-evolved microbes from next-generation sequencing data using breseq. Methods Mol. Biol. 1151, 165-188. doi: 10.1007/978-1-4939-0554-6_12

Duncan, T. V. (2011). Application of nanotechnology in food packaging and food safety: barrier materials, antimicrobials, and sensors. J. Colloid. Interface Sci. 363, 1-24. doi: 10.1016/j.jcis.2011.07.017

El Badawy, A. M., Silva, R. G., Morris, B., Scheckel, K. G., Suidan, M. T., and Tolaymat, T. M. (2011). Surface charge dependent toxicity of silver nanoparticles. Environ. Sci. Technol. 45, 283-287. doi: 10.1021/es1034188

Feng, Q. L., Wu, J., Chen, G. Q., Cui, F. Z., Kim, T. N., and Kim, J. O. (2000). A mechanistic study of the antibacterial effect of silver ions on Escherichia coli and Staphylococcus aureus. J. Biomed. Mater. Res. 52, 662-668. doi: 10.1002/10974636(20001215)52:4<662::AID-JBM10>3.0.CO;2-3

Franke, S., Grass, G., and Nies, D. H. (2001). The product of the ybdE gene of the Escherichia coli chromosome is involved in detoxification of silver ions. Microbiology 147, 965-972.

GE Health Life Sciences. (2014). Avaliable online at: http://www.gelifesciences. com/webapp/wcs/stores/servlet/catalog/en/GELifeSciences-US/applications/ nucleic-acid-sample-preparation/

Gottschalk, F., Sonderer, T., Scholz, R. W., and Nowack, B. (2009). Modeled environmental concentrations of engineered nanomaterials ( $\mathrm{TiO} 2, \mathrm{ZnO}, \mathrm{Ag}, \mathrm{CNT}$, Fullerenes) for different regions. Environ. Sci. Technol. 43, 9216-9922. doi: $10.1021 /$ es 9015553

Graves, J. L. (2014). A grain of salt: metallic and metallic oxide nanoparticles as the new antimicrobials. JSM Nanotechnol. Nanomed. 2:1026.

Gudipathy, S., and McEvoy, M. M. (2014). The histidine kinase CusS senses silver ions through direct binding by its sensor domain. Biochimica et Biophysica Acta. 1844, 1656-1661. doi: 10.1016/j.bbapap.2014.06.001

Gupta, A., Phung, L. T., Taylor, D. E., and Silver, S. (2001). Diversity of resistance genes in IncH incompatibility group plasmids. Microbiology 147, 3393-3402.

Gupta, A., and Silver, S. (1998). Silver as a biocide: will resistance become a problem? Nat. Biotechnol. 16:868. doi: 10.1038/nbt1098-888

Kedziora, A., Gerasymchuk, Y., Sroka, E., Bugla-Ploskonska, G., Doroszkiewicz, W., Rybak, Z., et al. (2013). Use of the materials based on partially reduced graphene-oxide with silver nanoparticle as bacteriostatic and bactericidal agent. Polim. Med. 43, 129-134.

Klasen, H. J. (2000). A historical review of the use of silver in the treatment of burns. Part I early uses. Burns 30, 1-9.

Li, Y., Bahti, P., Shaw, N., Song, G., Chen, S., Zhang, X., et al. (2008). Crystal structure of a novel non-Pfam protein AF1514 from Archeoglogus fulgidus DSM 4304 solved by S-SAD using a Cr X-ray source. Proteins 71, 2109-2113. doi: 10.1002/ prot.22025

Li, C., Kappock, T. J., Stubbe, J., Weaver, T. M., and Ealick, S. E. (1999). X-ray crystal structure of aminoimidazole ribonucleotide synthetase (PurM), from Escherichia coli purine biosynthetic pathway at 2.5 A resolution. Struct. Fold Des. 7, 1155-1166. doi: 10.1016/S0969-2126(99)80182-8

Li, X. Z., Nikaido, H., and Williams, K. E. (1997). Silver-resistant mutants of Escherichia coli display active efflux of $\mathrm{Ag}+$ and are deficient in porins. Bacteriol. 179, 6127-6132. 
Li, Y., Leung, P., Yao, L., Song, Q. W., and Newton, E. (2006). Antimicrobial effect of surgical masks coated with nanoparticles. J. Hosp. Infect. 62, 58-63. doi: 10.1016/j.jhin.2005.04.015

Liau, S. Y., Read, D. C., Pugh, W. J., Furr, J. R., and Russell, A. D. (1997). Interaction of silver nitrate with readily identifiable groups: relationship to the antibacterial action of silver ions. Lett. Appl. Microbiol. 25, 279-283. doi: 10.1046/j.1472-765X.1997.00219.x

Lok, C. N., Ho, C. M., Chen, R., Tam, P. K., Chiu, J. F., and Che, C. M. (2008). Proteomic identification of the Cus system as a major determinant of constitutive Escherichia coli silver resistance of chromosomal origin. J. Proteome Res. 7, 2351-2356. doi: 10.1021/pr700646b

McHugh, G. L., Moellering, R. C., Hopkins, C. C., and Swartz, M. N. (1975). Salmonella typhimurium resistant to silver nitrate, chloramphenicol, and ampicillin. Lancet 1, 235-240. doi: 10.1016/S0140-6736(75)91138-1

Mijnendonckx, K., Leys, N., Mahillon, J., Silver, S., and Von Houdt, R. (2013). Antimicrobial silver: uses, toxicity, and the potential for resistance. Biometals 26, 609-621. doi: 10.1007/s10534-9645-Z

Momtaz, H., Safarpoor Dehkordi, F., Taktaz, T., Rezvani, A., and Yarali, S. (2012). Shiga toxin-producing Escherichia coli isolated from bovine mastitic milk: serogroups, virulence factors, and antibiotic resistance properties. ScientificWorld Journal 2012:618709. doi: 10.1100/2012/618709

Nahku, R., Peebo, K., Valgepea, K., Barrick, J. E., Adamberg, K., and Vilu, R. (2011). Stock culture heterogeneity rather than new mutational variation complicates short-term cell physiology studies of Escherichia coli K-12 MG1655 in continuous culture. Microbiology 157, 2604-2610. doi: 10.1099/mic.0.050658-0

Quinn, H., Cameron, A. D. S., and Dorman, C. J. (2014). Bacterial regulon evolution: distinct responses and roles for the identical OmpR proteins of Salmonella Typhimurium and Escherichia coli in the acid stress response. PLoS Genetics 10:e1004215. doi: 10.1371/journal.pgen.1004215

Rai, M., Yadav, A., and Gade, A. (2009). Silver nanoparticles as a new generation of antimicrobials. Biotechnol. Adv. 27, 76-83. doi: 10.1016/j.biotechadv.2008.09.002

Rai, M. K., Deshmukh, S. D., Ingle, A. P., and Gade, A. K. (2012). Silver nanoparticles: the powerful nanoweapon against multi-drug resistant bacteria. J. Appl. Microbiol. 112, 841-852. doi: 10.1111/j.1365-2672.2012.05253.x

Rhee, J. E., Sheng, W., Morgan, L. K., Nolet, R., Liao, X., and Kenney, L. J. (2008). Amino acids important for DNA recognition by the response regulator OmpR. J. Biol. Chem. 13, 8864-8677. doi: 10.1074/jbc.M705550200

Riley, M., Abe, T., Arnaud, M. B., Berlyn, M. K., Blattner, F. R., Chaudhuri, R. R., et al. (2006). Escherichia coli K-12: a cooperatively developed annotation snapshot-2005. Nucleic Acids Res. 34, 1-9. doi: 10.1093/nar/gkj405

Sampei, G., and Mizobuchi, K. (1989). The organization of the purl gene encoding $5^{\prime}$-Phosphoribosylformylglycinamide aminotransferase of Escherichia coli. J. Biol. Chem. 264, 21230-21238.

Scheutz, F., and Strockbine, N. A. (2005). "Genus I. Escherichia, castellani and chalmers 1919," in Bergey's Manual of Systematic Bacteriology, Vol. 2, The
Proteobacteria, eds G. M. Garrity, D. J.Brenner, N. R.Kreig, and J. R. Staley (New York, NY: Springer), 607-624.

Silver, S. (2003). Bacterial silver resistance: molecular biology and uses and misuses of silver compounds. FEMS Microbiol. Rev. 27, 341-353.

Siqueira, M. C., Coelho, G. F., de Moura, M. R., Bresolin, J. D., Hubinger, S. Z., Marconcini, J. M., et al. (2014). Evaluation of antimicrobial activity of silver nanoparticles for carboxymethylcellulose film applications in food packaging. J. Nanosci. Nanotechnol. 14, 5512-5517. doi: 10.1166/jnn. 2014.8991

Tadesse, D. A., Zhao, S., Tong, E., Ayers, S., Singh, A., Bartholomew, M. J., et al. (2012). Antimicrobial drug resistance in Escherichia coli from humans and food animals, United States, 1950-2002. Emerg. Infect. Dis. 18, 741-749. doi: 10.3201/ eid1805.111153

Tajkarimi, M., Iyer, D., Tarannum, M., Cunningham, Q., Sharpe, I., Harrison, S. H., et al. (2014). The effect of silver nanoparticle size and coating on Escherichia coli. JSM Nanotechnol. Nanomed. 2:1025.

Xia, L. N., Tao, X. Q., Shen, J. Z., Dai, L., Wang, Y., Chen, X., et al. (2011). A survey of $\beta$-lactamase and $16 \mathrm{~S}$ rRNA methylase genes among fluoroquinolone-resistant Escherichia coli isolates and their horizontal transmission in Shandong, China. Foodborne Pathog Dis. 8, 1241-1248. doi: 10.1089/fpd.2011.0868

Xiu, Z. M., Zhang, Q. B., Puppala, H. L., Colvin, V. L., and Alvarez, P. J. (2012) Negligible particle-specific antibacterial activity of silver nanoparticles. Nano Lett. 12, 4271-4275. doi: 10.1021/nl301934w

Yamanaka, M., Hara, K., and Kudo, J. (2005). Bactericidal actions of a silver ion solution on Escherichia coli, studied by energy-filtering transmission electron microscopy and proteomic analysis. Appl. Environ. Microbiol. 71, 7589-7593. doi: 10.1128/AEM.71.11.7589-7593.2005

Conflict of Interest Statement: The authors declare that the research was conducted in the absence of any commercial or financial relationships that could be construed as a potential conflict of interest.

Received: 17 November 2014; accepted: 29 January 2015; published online: 17 February 2015.

Citation: Graves JL Jr., Tajkarimi M, Cunningham Q, Campbell A, Nonga H, Harrison SH and Barrick JE (2015) Rapid evolution of silver nanoparticle resistance in Escherichia coli. Front. Genet. 6:42. doi: 10.3389/fgene.2015.00042

This article was submitted to Evolutionary and Population Genetics, a section of the journal Frontiers in Genetics.

Copyright (c) 2015 Graves, Tajkarimi, Cunningham, Campbell, Nonga, Harrison and Barrick. This is an open-access article distributed under the terms of the Creative Commons Attribution License (CC BY). The use, distribution or reproduction in other forums is permitted, provided the original author(s) or licensor are credited and that the original publication in this journal is cited, in accordance with accepted academic practice. No use, distribution or reproduction is permitted which does not comply with these terms. 